\section{LIGAÇÕES PERIGOSAS? ALEXANDRE E ARISTÓTELES NOS FILMES DE MODI, ROSSEN E STONE}

\author{
Maria Cecília de Miranda Nogueira Coelho* \\ Recebido em: 09/03/2020 \\ Aprovado em: 30/04/2020
}

RESUMO: Considerando a controversa imagem de Alexandre, o Grande, que recebemos por meio dos textos da Antiguidade, não é de se espantar que sua representação no cinema seja também muito variada e complexa. O mais antigo e menos conhecido dos filmes sobre ele é Sikandar (1941, Índia), de Sohrab Modi, obra interessante não apenas porque a personagem é vista pela perspectiva dos conquistados, mas pela presença muito significativa de Aristóteles e Roxana. Posteriormente, sua história foi levada à tela nos filmes Alexandre o Grande (1956), de Robert Rossen, e Alexandre (2004), de Oliver Stone. Meu objetivo, neste artigo, é o de analisar aspectos desses três filmes, comparativamente, com atenção às imagens de Aristóteles, a fim de compreender como a presença do filósofo é retratada e alinhada à construção da imagem do rei macedônio.

PALAVRAS-CHAVE: Alexandre; Aristóteles; estudos de recepção; cinema.

\section{DANGEROUS LIAISONS? ALEXANDER AND ARISTOTLE IN THE FILMS BY MODI, ROSSEN AND STONE}

* Professora

Associada,

Departamento de

Filosofia, Universidade

Federal de Minas

Gerais.

ceciliamiranda@ufmg.br

ABSTRACT: Considering the controversial image of Alexander the Great that we receive via the texts of Antiquity, it should not surprise that his representation in the movies be also very much varied and complex. The most ancient and least known of the films about him is Sikandar (1941, India) by Sohrab Modi, an interesting work not only because the characters are portrayed from the perspective of the defeated, but by the meaningful presence of Aristotle and Roxane. Later on, his story was screened in Alexander the Great (1956), by Robert Rossen, and Alexander (2004) by Oliver Stone. My objective in this article is to analyze some aspects of these three films comparatively, focusing on the images of 
Aristotle, in order to understand how the presence of this philosopher is portrayed and aligned to the construction of the Macedonian king's image.

KEYWORDS: Alexander; Aristotle; Reception studies; Cinema.

\section{INTRODUÇão}

$\mathrm{E}$

ntre 2014 e 2016, alguns museus de cidades norte-americanas receberam uma exposição intitulada The Greeks - from Agamemnon to Alexander the Great, co-organizada pelo Ministério da Cultura e Esportes grego, que mostrava mais de 500 peças de vinte e uma instituições, inclusive algumas que nunca haviam saído da Grécia. ${ }^{1} \mathrm{Na}$ época, organizando um simpósio sobre a recepção do mito de Helena de Troia, o título acima chamou minha atenção, pois unia, como pontos extremos de um período de tempo, dois personagens famosos da cultura clássica, e também ocidental, sendo um deles Agamêmnon, personagem mítico, e o outro, Alexandre, personagem histórico. Como sempre considerei instigantes e perturbadores os versos de Fernando Pessoa no poema Ulisses, em seu livro Mensagem, de 1934: "Assim a lenda se escorre/ A entrar na realidade, / E a fecundá-la decorre", pensar na interação entre lenda e realidade, por meio da arte, seja no cinema ou na poesia, pareceu-me algo também instigante, sensação potencializada quando um terceiro elemento, como a história e a chamada realidade, entra em cena.

No caso da exposição citada, naturalmente é um título que atrai o leitor, o espectador, mas também, principalmente para o estudioso da cultura clássica, aponta para questões de trato difícil, como o de construir uma narrativa por meio de textos e imagens, associando de modo tão estreito uma figura mítica, como a de Agamêmnon, com a realidade histórica, a existência de Alexandre. A complexidade se revela, por exemplo, na obra de historiadores como Claude Mossé, cuja monografia, intitulada entre nós Alexandre, o Grande, possui, como título original Alexandre. La destinée d'un mythe - mudança curiosa, e mais rara de ser encontrada nos livros do que nos títulos de filmes, quando vão de um país para outro. Oportuno destacar que, descrevendo o momento em que o general macedônio, em sua jornada para a Ásia, se dirigiu a Troia, a pesquisadora francesa afirma o seguinte: "Grande leitor de poemas homéricos, como veremos, ele bancava o novo Agamenon, sem deixar de homenagear seu ancestral Aquiles, 'o melhor dos aqueus.'” (Mossé, 2004, p. 29). Se a associação é devidamente explicada por meio de detalhados capítulos, que analisam não apenas facetas dessa personagem histórica e suas próprias crenças mas também o que foi dito dele por autores variados desde a Antiguidade, ela o é a partir de interpretação de fontes que foram e estão sendo sempre relidas. Mossé já havia mostrado, ao apresentar, no seu O Processo de Sócrates, outra personagem complexa, como certos homens têm suas imagens

\footnotetext{
${ }^{1}$ Foram estes os museus onde ocorreram as exibições: Pointe-à-Callière, em Montreal; Canadian Museum of History, em Quebec; The Field Museum, em Chicago; e National Geographic Museum, em Washington. Um catálogo de autoria de Terence Clark, curador do Museu de Quebec, foi lançado em 2015, colocando em 134 páginas os textos e as imagens da exposição.
} 
(re)construídas ao longo do tempo, de maneira, muitas vezes, até inconsistente. Nas duas obras há espaço para capítulos que, se não discutem detalhadamente os processos e as razões de (re)construções de imagens, apontam para o problema metodológico de lidar com as várias imagens. ${ }^{2}$ Nesse sentido, o mais importante é que qualquer historiador deixe claras as escolhas ao se propor reconstruir uma época do passado, ou uma personagem, ou um grupo delas. Saber dessas escolhas é um primeiro passo para minimizar equívocos interpretativos e afirmações categóricas em terrenos que são como um campo minado. ${ }^{3}$ Como observa Ian Worthington - no capítulo "How 'Great' was Alexander?”, que encerra seu livro Alexander the Great. A Reader, organizado com a contribuição de outros historiadores, com vozes dissonantes -, o problema da inexistência de fontes primárias, tendo de se confiar no que foi escrito por autores como Diodoro, Curtius, Arriano e Plutarco, com base em cerca de 40 relatos que foram escritos na época em que Alexandre viveu (ou imediatamente após sua morte), sem saber o modo como esses autores usaram suas próprias fontes e o quanto foram influenciados pelo ambiente romano no qual estavam, e pelo que, mais recentemente, ao tratar do problema da relação entre retórica e veracidade na oratória grega, por meio do exemplo dos discursos de Demóstenes e Ésquines, ele chamou estes de “motivation” (2019, p. 1) dos oradores, cujas obras, por sua vez, serviram como fontes para historiadores posteriores. Para Worthington, é crucial, ao mostrar que tanto fontes antigas como interpretações mais recentes impossibilitam uma interpretação única da figura de Alexandre, ter o leitor que "tirar suas próprias conclusões" (2003, p. viii) a partir de suas escolhas conscientes de tais fontes.

Considerando as controversas imagens de Alexandre que recebemos por meio dos textos da Antiguidade e das modernas interpretações (uma delas a de Worthington - um dos mais radicais críticos da alegada grandeza do rei macedônio, principalmente se comparada à de seu pai, Felipe, pelo menos como legislador, e não como conquistador), não é de se espantar que sua representação no cinema seja também muito variada e complexa. Os três filmes de que vamos tratar aqui - Sikandar (1941), produção indo-iraniana dirigida por Sohrab Modi, Alexandre o Grande (1956) e Alexandre (2004), produções americanas dirigidas por Robert Rossen e Oliver Stone, respectivamente - mostram personagens bem diferentes. ${ }^{4}$

\footnotetext{
${ }^{2}$ No livro sobre Sócrates, destaco o item "O desenvolvimento do mito de Sócrates”, p. 52-7, cuja brevidade não compromete sua qualidade. Sobre a mitologização da figura histórica do filósofo, veja, também, Coelho (2015), analisando o padrão comum no julgamento de três personagens inocentes: Hipólito, na peça homônima de Eurípides; Palamedes, da Apologia, de Górgias; e Sócrates, na Apologia, de Platão.

${ }^{3}$ A questão, que afeta também qualquer historiador da filosofia, é colocada de modo muito pertinente por Livio Rossetti (2006), principalmente nos capítulos 7, 8, 12 e 13.

${ }^{4}$ Se não foi levado à tela tantas vezes como o famoso romance epistolar Les Liaisons Dangereuses, de Choderlos de Laclos (onze vezes adaptado para o cinema), as três vezes que analisamos aqui já mostram como houve um rico debate para os estudos clássicos e sua recepção. No entanto, vale notar que há duas outras obras cinematográficas que retomam, em processos de transposição e releitura, de maneira bem diferentes, a personagem lendária: o seriado Reign: the Conqueror (1999, Japão), de Yoshinori Kanemori, e o cult O Megalexandros (1980, Grécia), de Theo Angelopoulos. Esta última, desviando do mito tradicional do herói, o reinstaura, porém, sob outra ótica. Há também o curta
} 
Além disso - vale lembrar um truísmo! -, mesmo filmes que têm como protagonistas figuras reais têm outros objetivos que não a veracidade histórica, ainda que sejam fruto de um dedicado trabalho de pesquisa e se apoiem em historiadores como consultores, como foi o caso do polêmico filme de Stone, que, além do longo trabalho de pesquisa do diretor, contou com a assistência de Robin Lane Fox e de Lloyd Llewellyn-Jones. ${ }^{5}$ Aqui é oportuna uma palavra sobre o modo como o cinema representa figuras históricas que se tornaram legendárias, em parte por sua conexão com personagens míticas, sendo a própria sétima arte um instrumento para a manutenção e (re)construção de mitos. Por um lado, temos de notar que, ao tratar da recepção de Alexandre no cinema, devemos considerar, como disse muito bem Kim Shahabudin (2004, p. 97), que "grandes épicos do cinema operam simultaneamente em dois níveis: interrogam velhos mitos e criam novos"; por outro, estudiosos de recepção não devem deixar de ver que, nesse caminho de mão dupla, as fronteiras entre mito, ficção e história podem ser beneficamente diluídas tanto para os espectadores como para os que trabalham diretamente como consultores. Vale citar a observação de Joanna Paul (2004, p. 24-5), que não apenas destaca a importância do cinema como instrumento da nova mitologização da Antiguidade como enfatiza a relevância de comentários como os de Lane Fox e de Llewellyn-Jones, para os quais a cooperação com Stone os fez questionar certas crenças que tinham sobre Alexandre.

Que o cinema tenha se tornado objeto de estudo de classicistas é o que obras como de Paul Cartledge e Fiona Greenland, sobre Alexandre, ou de Martin Winkler, sobre Gladiador e Troia, mostram, dentro da área mais ampla de estudos de recepção. Que os interessados no assunto tenham de se debruçar sobre a área de Estudos Fílmicos, para, pelo menos, evitar desconsiderar elementos como montagem, mise-en-scène, figurino, música, cinematografia, ampliando as dificuldades de um tratamento sério de obras cinematográficas, não resta dúvida, o que torna o assunto mais trabalhoso. Além disso, naturalmente, é conveniente observar que essas obras estão em diálogo com outros filmes, no caso de Alexandre, principalmente aqueles do gênero épico, que lhes são contemporâneos, além de atender a certas normas da indústria de entretenimento, que, por sua vez, tem de se adequar a padrões morais e a interesses políticos nos países em que são produzidos. Por fim, é ainda importante notar que, por várias razões (inclusive a possiblidade de ter acesso aos filmes fora das salas de cinema, por meio de fitas de vídeo, DVDs, Blus e, agora, acesso on-line), pesquisas nessa área eram praticamente inexistentes - uma comparação sobre o número de textos de classicistas analisando épicos da fase áurea do gênero (entre os anos 50 e 60) indica isso. ${ }^{6}$ Vale lembrar

francês Roxane (2018, França), de Vanya Chokrollahi, e O Homem que queria ser rei (1975, Estados Unidos), de John Huston - baseado no conto de Rudyard Kipling (interpretado por Christopher Plummer, que faz Aristóteles no filme de Oliver Stone).

${ }^{5}$ Naturalmente a consultoria não atesta fidelidade a qualquer perspectiva histórica. Sobre a relação entre consultores e diretores/produtores, veja Coleman (2004), e sobre os problemas de autenticidade e precisão com as fontes (históricas ou não), veja Gamel (2004) e a introdução de Winkler (2004).

' Para citar alguns exemplos: Ulisses (1955), Helena de Troia (1956), Jasão e os Argonautas (1963), Spartacus (1960) e A queda do Império Romano (1964). 
que épicos dominaram a história do cinema (desde Quo Vadis?, de Enrico Guazzoni, em 1912), entre os anos de 1950 e 60, e seu ressurgimento ocorreu com o lançamento de Gladiador (2000, Ridley Scott) em uma década que viu Troia (2004) e Alexandre (2004), tendo estes três últimos recebido enorme atenção e se tornado objeto de estudos e publicação na área acadêmica.

Feitas essas considerações, passarei a uma análise de alguns aspectos dos três filmes sobre Alexandre citados acima, invertendo a ordem cronológica de apresentação, em parte porque foi a polêmica causada por Alexandre, de Stone, que reativou o debate sobre a relação entre história antiga e cinema, em estudos que ajudaram a consolidar a área de recepção e a mostrar os problemas metodológicos ligados a ela, mas também porque após seu lançamento vieram à luz análises de filmes mais antigos como os de Rossen e Modi, sobre o quais os classicistas não haviam se debruçado antes. ${ }^{7}$ Por fim, é importante explicar e justificar que, embora esses três filmes sejam o objeto de meu estudo, como indico no título e informo no resumo, não pretendo fazer uma análise geral, relacional entre eles, tampouco compará-los com textos que lhes serviram como fontes nem mesmo estudar aspectos da reconstrução de Alexandre per se. Limito-me, por várias razões, investigando a presença de Aristóteles, a destacar em que medida sua presença, comparando-a em certos momentos com a de Felipe, influencia na construção da imagem de Alexandre.

Aristóteles está presente nos três filmes citados - diferentemente de seu sobrinho Calístenes, que acompanhou Alexandre em sua jornada para a Ásia -, certamente por ter sido morto por ordem de Alexandre, o que seria problemático em qualquer filme. ${ }^{8}$ A relação entre Alexandre e os filósofos e oradores se insere em um tema mais amplo e cativante, explorado por Koulakiotis, que estudou a interação entre intelectuais e líderes no período clássico, em particular aquela entre reis macedônios e membros da academia de Platão. ${ }^{9}$ Como se sabe, a escolha de Aristóteles por Felipe não é um tema desvinculado de visões concorrentes sobre filosofia e política. Em carta a Alexandre, Isócrates, que, apesar da crítica platônica,

\footnotetext{
${ }^{7}$ É oportuno também remeter para dados pesquisados pelo professor de arqueologia e antropologia John Cherry (2010, p. 307), que traz uma tabela detalhada do aumento significativo, após o lançamento do filme de Stone, analisando as publicações e exibições em museus ligados a Alexandre, entre 2002 e 2007 (algumas muito oportunistas), e realçando as dificuldades dessas empreitadas (p. 229).

${ }^{8}$ A discordar da ordem de Alexandre em relação à introdução do gesto da prosquínese (ajoelharse em sinal de subalternação diante do rei), visto por um grego como sinal dos povos bárbaros, o historiador, encarregado de narrar (e embelezar) a vida de Alexandre, como nota Worthington (2003, p. 309-10), foi posteriormente acusado de conspirar contra o rei e morreu na prisão. Críticos da faceta tirânica de Alexandre, como Quintus Curtius, que, como observa Asirvatham (2012, p. 315), nunca mencionou Aristóteles em sua obra sobre Alexandre, veem Calístenes como herói.

${ }^{9}$ Veja Koulakiotis (2018a e 2018b). O primeiro texto, diga-se de passagem, foi publicado no Terceiro Companion, que a editora Brill lançou sobre Alexandre (os outros dois foram de 2002 e 2011 - sobre a recepção de Alexandre na literatura medieval), o que mostra a vastidão de temas ainda em debate. $O$ mesmo capítulo que está na Brill, bem como o segundo texto de Koulakiotis, também foi apresentado como palestra na Universidade Federal de Minas Gerais, em 2018.
} 
entende que sua visão filosófica era a mais adequada para a formação de cidadãos, sugere que o jovem de 14 anos e sob a tutela de Aristóteles, não se dedique a diatribes e a questões erísticas, mas se preocupe com uma paideia que o leve a ter uma sabedoria prática (phronesis) como a de seu pai. ${ }^{10}$ A complexidade da interação entre Alexandre com filósofos e com a filosofia (e a oratória e a retórica) é ampliada, em parte pelos relatos de seus biógrafos e pelo valor que essas disciplinas adquirem para eles em função de suas convicções do papel que a filosofia deve ter na esfera política. Além de Koulatiokis, que investiga as imagens que Alexandre tem por meio dos textos dos oradores áticos, que atuam na realpolitik grega, para preocupação de Platão e Aristóteles, o tema é também tratado (e ampliado) por Sulochana Asirvatham a partir de outra ótica, e algumas de suas observações são oportunas de serem apresentadas aqui.

A fim de compreender o que implica trazer para um filme sobre Alexandre a sua interação com Aristóteles, creio ser necessário apontar para um dos corolários da associação entre Alexandre e a filosofia, ${ }^{11}$ qual seja, o seu desejo de unificar a humanidade em uma irmandade cosmopolita (Tarn seria um dos defensores dessa visão, apoiado em Plutarco). Asirvatham nota que em um dos livros mais antigos publicados na Inglaterra, The Dictes and Sayings of the Philosopher (1477), que remonta à tradição árabe, Alexandre tem seu próprio capítulo. Na sua investigação entre a visão, no âmbito da história do conquistador macedônio, do que seja filosofia no Oriente e no Ocidente, a autora analisa as referências nas fontes grecoromanas a Aristóteles e a Calístenes, bem como os encontros de Alexandre com Diógenes e os gimnosofistas indianos. Deve ser notado, porém - e é o que me interessa aqui -, que "most of writer's priority was not to 'do justice' to either Alexander or to a specific philosophical school or philosopher, but to promote a particular idea of philosophy that happened to be relevant to world-conquest" (Asirvatham, 2012, p. 312). A denominação por Plutarco de Calístenes como filósofo, ou mesmo de Alexandre, portador de uma alma filosófica e admirador dos sábios, indica o quão nebulosa é a fronteira entre o que se generalizou como filosofia e história. Plutarco chega a dizer, comparando Alexandre a Pitágoras, a Sócrates e a outros que não deixaram nada escrito, que ele teria mais razão de fazer isso, considerando que nenhum dos outros havia se ocupado com guerras e fundação de cidades gregas entre os bárbaros (Sobre a Fortuna e Virtude de Alexandre, 328b-c), e certos traços de Alexandre como filósofo, por sua defesa da homonoia, koinonia e de uma vida simples, sem luxos, irão perdurar até o Romance de Alexandre, de Pseudo-Calístenes (no qual a presença de Aristóteles é bastante limitada), ${ }^{12}$ o que indica como a caracterização da atividade filosófica era flexível. Certamente, pela fama de Aristóteles e talvez, mesmo por Alexandre, segundo Plutarco (ibid., $329 \mathrm{~b})$, ter-se recusado a tratar os bárbaros do modo como seu mestre propusera - o que realçaria ainda mais a ousadia do jovem discípulo -, ele é a personagem mais adequada para

\footnotetext{
${ }^{10}$ Sobre mais detalhes dessa carta, bem como a obra de Isócrates e sua defesa do pan-helenismo, veja Papillon (2007, p. 58 e ss).

${ }^{11}$ Vale lembrar que não há, na obra de Aristóteles, nenhum comentário a Alexandre. Veja AristotleJones (1984).

${ }^{12}$ Sobre esta obra do século III, veja Rabelo (2017).
} 
aparecer na tela, simbolizando uma educação filosófica e colocando o jovem protagonista com o melhor dos melhores, pelo menos nos dois filmes americanos, pois no indiano a representação do estagirita é outra, ainda que, ali também, o discípulo vá contrariar os conselhos do mestre. Passemos aos filmes, interessados, precipuamente, no modo como se articula a imagem entre discípulo e mestre.

\section{“UM HOMEM ASSIM COMO AlEXANDRE EXISTIU? É ClARO QUE NÃO.” Ptolomeu (Alexandre)}

A versão que utilizarei aqui é aquela lançada nos cinemas, em 2004, com 175 minutos, disponível hoje em canais como Netflix, o que a torna a mais acessível. Houve uma versão de 167 minutos, lançada em DVD (e com a inserção de uma cena com Aristóteles), uma segunda, chamada "the final cut", em 2007, com 214 minutos, na qual a estrutura foi bastante mudada e as cenas iniciais de formação, digamos, em encontros com sua mãe, seu pai e Aristóteles, foram todas transferidas para outros momentos do filme, funcionando como flashbacks, relembrados por Alexandre. Há ainda uma terceira versão apenas em DVD, de 2014, com 207 minutos. Um estudo comparativo seria interessante, caso meu objetivo fosse tratar apenas da presença de Aristóteles neste filme, mas não é o caso aqui; então usarei aquela que foi levada para o cinema e hoje é a mais acessível ao público. ${ }^{13}$

Muitos estudos já foram publicados sobre o filme, cobrindo os mais variados aspectos da recepção de Alexandre no cinema. ${ }^{14}$ Por isso, não se trata, neste artigo, de retomar o que já foi dito ou de resumir o filme tão conhecido - aliás, suponho que meu leitor já assistiu ao filme. Tanto quanto tenha pesquisado, nenhum texto tem o enfoque comparativo que estou dando aqui, a partir da personagem de Aristóteles nos três filmes. Antes de destacar alguns momentos da representação de Aristóteles como professor de Alexandre, que recebe de sua mãe e de seu pai lições importantes (às quais farei breve menção, na medida em que são articuladas com aquelas de seu mestre), é importante informar sobre a alteração dessas cenas na versão final que Stone deu ao filme, e neste momento é pertinente trazer as palavras do próprio diretor. Em um volume organizado por Greenland (doutora em arqueologia por Oxford e consultora no filme) e Cartledge (professor de cultura grega em Cambridge), após Stone ter lançado em DVD, em 2007, a sua versão final (a terceira) do filme, há um debate importante. Publicado em 2010, seis anos após o lançamento de Alexandre, este livro é apresentado como um conjunto de respostas de renomados classicistas em sua polêmica obra. ${ }^{15}$ Acostumados que estamos a tratar com obras de arte da Antiguidade a partir apenas

\footnotetext{
${ }^{13}$ Para um estudo comparativo, com excelente comparação entre as três primeiras versões, ilustradas por um conjunto de fotogramas, veja Idaho (2011).

${ }^{14}$ De todos que consultei, cito apenas os que selecionei para esta pesquisa: Berti; Morcillo (2008), Petrovic (2008), Chaniotis (2008), Wieber (2008), Winkler (2009) e todos os 12 artigos em Cartledge; Greenland (2010).

${ }_{15}$ Ao defender certas escolhas de Stone e chamar atenção para a diferença de perspectiva de um diretor e um acadêmico, John Solomon (2010, p. 37), um dos nomes mais respeitados nos estudos
} 
das próprias obras, a situação do artista estar presente, por meio de reportagens, entrevistas e making offs, podendo responder e comentar sobre aspectos de seu trabalho, leva-nos à, metodologicamente, trabalhar de modo diferente. No caso de Stone, quando lemos seu Afterword, escrito a partir do acesso que teve aos artigos de todos os outros renomados pesquisadores, encontramos um comentário esclarecedor. Ao falar da alteração que fez na estrutura do filme, ele diz que a razão foi uma insatisfação que veio ao encontro daquilo que também foi observado por Joanna Paul (2010, p. 28) em um dos artigos do mesmo livro. A historiadora se pergunta o que teria acontecido se Stone tivesse - como Alexandre - "escutado cuidadosamente Aristóteles", referindo-se à unidade de ação defendida na Poética (1451a, 1459a) e ausente no filme. Foi justamente uma insatisfação (aristotélica!) com a primeira versão que o levou a alterar a estrutura e, além de incluir muitas cenas cortadas, mudar o início do filme e transferir para depois a terceira parte da sequência da primeira versão: morte de Alexandre, relato de Ptolomeu, juventude de Alexandre e batalha de Gaugamela. Nas palavras de Stone (2010, p. 342), "the earlier version, showing the young boy's growth, sowing the seeds of the man before we'd ever seen him, I found too conventional in hindsight", pois as cenas de sua formação familiar e com Aristóteles ganhariam mais peso e significado após suas vitórias, em particular em Gaugamela, dando uma maior unidade de ação em todo o filme (2010, p. 342). Mas, como disse antes, vou partir da versão exibida nos cinemas em 2004 e ainda disponível.

Alexander, título original, que aparece sobre a famosa escultura da cabeça de Alexandre, ${ }^{16}$ se inicia com a cena de sua morte, ${ }^{17}$ para, em seguida, mudar para o relato do velho Ptolomeu (Anthony Hopkins) narrando, na biblioteca de Alexandria (um local que confere tanta autoridade como a própria presença de um filósofo como Aristóteles), a história daquele "homem colossal", um "Prometeu", que criou 18 Alexandrias e disseminou a civilização helênica. Antes de descrever os lugares conquistados, e falar "do olhar de Alexandre que transmitia o desejo de fazer qualquer coisa", Ptolomeu se pergunta: "Como posso contar?... Só agora já velho posso entender essa força da natureza. Ou será que não? Um homem assim como Alexandre existiu? É claro que não. Eles o idolatram, o tornam melhor do que foi." Essa narrativa, ao mesmo tempo que interroga sobre sua precisão, repõe, ao narrar os fatos e mostrar imagens (mapas, esculturas, cenário verossímil), e reforça a lenda. Contradições como a afirmação inicial melancólica "Nosso mundo não existe mais, destruído

clássicos e cinema, questiona tanto as críticas de outros colegas (como as de Worthington) como a de críticos profissionais e público em geral, baseadas no que ele chama de as três regras do "Canon of Film non-Criticism" (algo que ele nunca permite seus alunos fazerem quando ensina cinema), isto é, ataques que começam com afirmações superficiais como: "It was too long", "It was boring", "It was not like the book".

${ }^{16}$ Que hoje se encontra no Museu Britânico. Sobre as obras de arte utilizadas no filme, veja Platt (2010).

${ }^{17}$ Sobre cenas da morte nas biografias, em particular nas Vidas, de Plutarco, veja Pinheiro (2018). Como o historiador, Stone não reforça a cronologia, mas rearticula cenas da vida que reforçam um ethos de Alexandre. Plutarco como fonte para Stone, veja Chaniotis (2008) e Petrovis (2008); para Rossen, veja Wieber (2008). 
pelas guerras (grifo meu). Agora eu sou o guardião de seu corpo, embalsamado aqui, como faraó" não são compatíveis com o encômio daquele que fez tudo isso por meio das armas, da guerra. ${ }^{18}$ Mas essas contradições empalidecem diante da narrativa que segue elogiando Felipe II (Val Kilmer) e transferindo a cena para o ambiente mágico do quarto de Olímpia (Angelina Jolie) com seu pequeno filho, a quem ela ensina a lidar com serpentes e cantarola docemente enquanto fala de Dioniso, até a entrada de seu marido, bêbado (mas que não sabe honrar o deus do vinho), que tenta violá-la na frente de Alexandre (Jessie Kamm). Ajudada pelo filho e por serviçais a repelir o marido, que a acusa de tê-lo traído, Olímpia diz que do seu ventre nasceu um "vingador", aludindo à natureza divina de Alexandre. ${ }^{19}$ Certamente, a primeira aparição de Felipe não faz jus ao grande político, ${ }^{20}$ muito pelo contrário.

A cena muda para oito anos depois, com voz over de Ptolomeu, que, comentando uma derrota de Alexandre, já garoto (Connor Paolo), na palestra, por Heféstio (Patrick Carroll), afirma que depois seria dito que Alexandre nunca teria sofrido nenhuma derrota, exceto pelas coxas de Heféstio. ${ }^{21}$ Neste momento da narração, a cena já vai sendo transferida, com a câmera fazendo uma panorâmica sobre uma paisagem idílica, seguida de ruínas majestosas de uma construção (algo que se torna símbolo do que hoje associamos à Grécia: restos de colunas brancas ${ }^{22}$ ), para Alexandre, com outros meninos recebendo lições de geopolítica de um simpático e paciente Aristóteles (Christopher Plummer ${ }^{23}$ ).

\footnotetext{
${ }^{18}$ Pode ser instrutivo trazer, aqui, a discussão sobre nosso engajamento contraditório em relação ao prazer de ver/ler sobre espetáculos de guerra, a partir do texto fundante da Ilíada. Veja Meyers (2016). ${ }^{19} \mathrm{O}$ termo remete a Pseudo-Calístenes (Vida de Alexandre 1,7), mas, ali, dito por Nectanebo, após entrar no quarto da rainha, unir-se a ela e dizer: "Conserve-se, mulher, você tem no ventre um menino que será seu vingador, rei de todo o mundo habitado e senhor do universo”. Veja Rabelo (2017). ${ }^{20}$ Em favor de sua grandeza, obnubilada pela do filho, veja Worthington (2014).

${ }^{21}$ A questão da homossexualidade no filme é bastante complexa. Paul (2010, p. 17-8), lembrando que o filme foi intitulado "Alexander, the Gay", informa como a representação de um protagonista bissexual causou a ira do então Ministro da Cultura grego, Venizelos, que retirou o apoio ao projeto. Já Solomon, lembrando o preconceito em certas áreas dos Estados Unidos, como o cinturão bíblico, lembra também de como a filmografia de Stone mostra um cineasta que sempre se preocupou com a desconstrução de ícones da cultura (2010, p. 43-6). Sobre temas de gênero no filme, veja os artigos de Cyrino, Reames, Skinner e Carney, no livro de Cartledge e Greenland (2010), que não estão nas referências bibliográficas por eu não os ter usado aqui.

${ }^{22}$ No entanto, segundo Fox (2010, p. 69), para Stone, elas representariam um mundo que está desaparecendo.

${ }^{23}$ Para Paul (2010, p. 26), o uso do ator engaja na inserção do filme em uma tradição cinematográfica épica, pois Plummer foi Commodus em $A$ queda do Império Romano. Lembro também que ele fez Kipling em $O$ Homem que queria ser rei.
} 


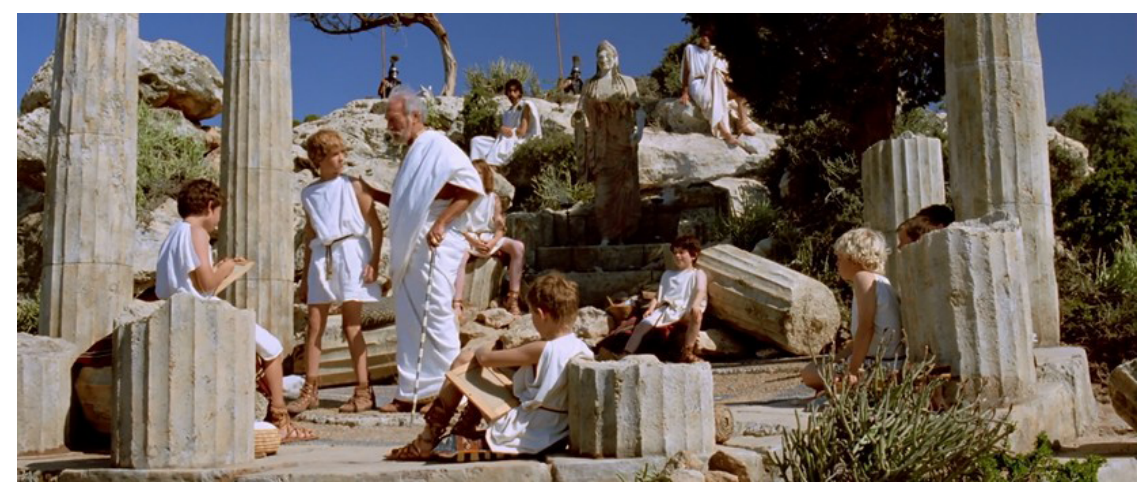

FIGURA 1 - Alexandre: Aristóteles, com Alexandre e outros alunos ${ }^{24}$

Ouvimos primeiramente as palavras do filósofo, enquanto alguns meninos anotam a aula: "Embora, de uma raça inferior, os persas controlam pelo menos quatro quintos do mundo conhecido." ${ }^{25}$ Em seguida, com a câmera focalizada em um mosaico no qual está desenhado o que se acreditava então ser o mundo, Aristóteles apresenta a hipótese de o rio Nilo receber águas das distantes montanhas nos confins do Leste, acima da Índia. Observado pelas faces curiosas dos alunos, ele continua dizendo que, se for assim, "um navegador experiente poderia encontrar um caminho saindo das montanhas e descendo pelo Leste para a planície da Índia, navegando pelas bordas do grande oceano até chegar ao rio Nilo, e, subindo, chegar ao Egito e, daí, retornar à Grécia.” Espantado com a falta de interesse dos gregos em fazer esse trajeto e em função de sua posição central no mapa para "dominar o mundo", ${ }^{26}$ Aristóteles é interpelado por Alexandre, este entusiasmado com essa possibilidade: "Por que, mestre, nos mitos, essas terras de que fala são conhecidas?" - justificando que todos os homens que foram para o Oriente (Héracles, Dioniso, Jasão, Teseu, Aquiles) foram vitoriosos. Afinal, não deveria ser verdade o que foi passado de geração em geração? A resposta de Aristóteles é de que, como a lenda das Amazonas, são histórias nas quais o povo acredita, mas que pessoas educadas e treinadas para esquecer suas paixões não devem acreditar nelas. A objeção de Alexandre sai da esfera do mito e retoma o ponto iniciado por Aristóteles: "Mas se somos superiores aos persas, como você diz, por que não os dominamos? Nosso sonho grego sempre foi rumar para o Oriente.” Com olhar grave, o mestre encerra a intervenção de Alexandre dizendo que "o Oriente costuma

\footnotetext{
${ }^{24}$ Esta foto, como as duas outras seguintes, são um screenshot do filme e sua reprodução está de acordo com as normas de citação de imagem vigentes.

${ }^{25}$ Como se sabe, o tema da escravidão (natural) é desenvolvido no livro I da Política, no contexto da diversidade de tipos de autoridade política e autonomia deliberativa (negada a muitos bárbaros, mesmo que vivam em sociedades bem organizadas), tratando-se, porém, de uma questão muito mais complexa do que as breves afirmações tanto do Aristóteles de Stone como o de Rossen possam sugerir. Veja Heath (2008) e Smith (1983).

${ }^{26}$ Sobre essa posição geográfica entre dois extremos (Europa e Ásia) significar também uma posição cognitiva superior (equilíbrio entre inteligência e coragem), veja Política VII.7.
} 
engolir os homens e seus sonhos". A aula continua com uma pergunta de Nearco (Peter Williamson) sobre a razão de os persas serem considerados cruéis. Aristóteles responde atribuindo à barbárie e à devoção aos sentidos, acrescentando que os gregos são superiores porque fogem dos excessos e controlam os sentidos. Por fim, Cassandro (Morgan Ferris) pergunta se o excesso de Aquiles deve ser condenado, ocasião propícia não apenas para Aristóteles criticar o egoísmo do herói, na sua vingança pela morte do "amante" Pátroclo, mas também para desaprovar a união de dois homens que visam à satisfação dos prazeres, e não ao aprimoramento moral que um pode trazer ao outro quando compartilham "virtude e conhecimento" e competem pela excelência, que leva à construção da cidade-estado.

A lição termina com a entrada da voz over de Plutarco, enquanto os meninos descem e correm por uma campina, informando que Felipe levou pessoas cultas como Aristóteles para educar o povo inculto. São esses exíguos quase quatro minutos a primeira e única aparição de Aristóteles, seguida pela cena do famoso episódio da doma de Bucéfalo, no qual o diretor reforça o aspecto rude de Felipe, ao recusar comprar um cavalo indomável, dizendo: "quem irá querer uma fera dessas, já tenho uma esposa." 27 Quando seu filho mostra sua ousadia e habilidade para montá-lo, seu pai, orgulhoso, o carrega e em seguida ambos já estão em uma caverna, com pinturas referentes a Aquiles, Édipo, Medeia, Prometeu e Héracles, cujos mitos são relatados por Felipe ao filho. Esta é uma cena muito discutida sob várias perspectivas. ${ }^{28}$ A meu ver, ela complementa a cena escolar, ao opor a visão de Alexandre à de Aristóteles, na medida em que a crítica do filósofo à crença nos mitos, bem como sua condenação do destempero de Aquiles, não parecem ter impacto sobre o menino, cujo desejo é ser como o herói e, quiçá, ter sua imagem retratada naquelas paredes. Por outro lado, diferentemente de Ptolomeu, Felipe considera Prometeu "um infeliz", mas tem uma percepção mais carregada de pathos que Aristóteles, que está, aliás, mais próxima da de seu filho. Se os mitos não podem ser lidos literalmente, como adverte Aristóteles, quando Alexandre fala deles no contexto das viagens para o Oriente, eles podem servir como exemplos de comportamentos excessivos, o que Aristóteles e Felipe tentam mostrar, o primeiro condenando os excessos de Aquiles, e o segundo, os dos personagens retratados na caverna, ${ }^{29} \mathrm{em}$ particular de Medeia, pois quando

\footnotetext{
${ }^{27}$ Sobre a tradição de associar mulheres, heróis e cavalos (que começa com Homero), veja Coelho (2017) e também Lopes da Costa (2019), unindo a tradição homérica àquela de Guimarães Rosa. Relembro, ainda, o poder simbólico desse episódio, por meio do filme de François Truffaut, Os incompreendidos (1959), a cena do protagonista Doinel (J. P. Léaud) na casa do melhor amigo, que tem no quarto um cavalo chamado Bucéfalo.

${ }^{28}$ Segundo Paul (2010, p. 26) e Platt (2010, p. 298), a cena é, também, reflexiva: se virmos a caverna de Platão como um protocinema, Alexandre deve ser visto, aqui, como os heróis que seu pai mostra. Vários estudos sobre o filme se detêm nessa cena, mas para uma análise mais detalhada, analisando todas as outras imagens da tradição utilizadas por Stone, seja como citação ou pastiche, veja Platt (2010, p. 288-93).

${ }^{29}$ É interessante notar que a educação de Alexandre é compatível com a descrição que Platão faz, no contexto da narração do mito de Prometeu e da criação dos homens, no Protágoras, quando é afirmado que, ligada à educação dada pelos pais, os mestres devem ensinar os poemas dos bons poetas, suas admoestações para que os imitem, e os pedótribas, a educação física (Prot. 325b-26e).
} 
Alexandre expressa o carinho de Olímpia, ao dizer "minha mãe nunca the faria mal", Felipe responde que não é fácil se libertar das mães e alerta que as mulheres são mais perigosas que os homens ${ }^{30}$ (momento em que a câmera focaliza serpentes verdadeiras coleando nas pedras).$^{31} \mathrm{~A}$ lição de Felipe termina com o lamento pela solidão do poder (seguido da ingestão de bebida, que sempre o acompanha).

Aristóteles e Felipe são as influências mais importantes na formação de Alexandre (Olímpia também tem grande influência, mas de outra maneira que não será discutida aqui). Em relação ao papel do mito, a lição do segundo tem mais peso, mas em relação ao desejo de conquista (pothos), ele é instilado por Aristóteles, e sua concepção da superioridade dos gregos é garantia para a adesão dos jovens (e de muitos espectadores) para justificar as conquistas de Alexandre. Embora não apareça mais ao longo do filme, como personagem, Aristóteles será citado em alguns momentos importantes. Quando entra na Babilônia - aclamado como "Sikandar" realizando (voz em over do velho Ptolomeu) "um sonho tão mítico para os gregos como Aquiles derrotando os troianos", admirando a grandiosidade e a arquitetura -, ele ouve de Ptolomeu (Robert Earley): "Aristóteles pode tê-los chamado de bárbaros, mas nunca viu a Babilônia". Ao chegar ao harém, Alexandre (Colin Farrell) afirma que seu mestre foi "profético" e se pergunta: "essas imagens não nos enganarão com sua beleza e degradarão nossa alma?" Posteriormente, ao se decidir por ficar na Ásia, cita novamente Aristóteles e diz que ele estava errado sobre os persas. A penúltima referência ocorre quando Alexandre decide seu casamento com Roxana (Rosário Dawson). Ao ser admoestado para se lembrar do que Aristóteles disse sobre os bárbaros, é questionado por Cassandro (Jonathan Meyers): "Uma rainha asiática!? O que são votos para uma raça que nunca manteve a palavra conosco?" Sua reação é violenta por perceber que todos desconsideram não apenas suas palavras como o fato de serem os asiáticos um povo mais antigo que eles, após exclamar: "Aristóteles que se dane!". A última referência ocorre quando, antes de descer para Índia, ao observar as montanhas onde Prometeu havia sido aprisionado, a visão aristotélica de um mundo limitado pelo oceano exterior é questionada. É também neste momento que Alexandre reafirma sua necessidade de uma busca incessante, sem conseguir se fixar em nenhum lugar, trazendo uma tonalidade trágica e heroica para seu personagem.

Na cena em que o ataque a Dario é planejado, e na qual Alexandre nega a política de seu pai, feita por meio de casamentos, ${ }^{32}$ Cassandro lembrará que Alexandre, embora o pai dele não gostasse de Homero, dorme com a Ilíada sob o travesseiro. Posteriormente, no leito de morte, Heféstio irá comparar Alexandre a Aquiles e a Prometeu, falando da beleza do mito e de como Alexandre venceu o coração dos homens. A morte de Alexandre oito meses depois consolidará essa posição, corroborando o que Ptolomeu já havia anunciado antes,

\footnotetext{
${ }^{30}$ Quando já adulto, Olímpia reclama da nova esposa de Felipe e sugere a ele ter um herdeiro, como sucessor; Alexandre inverte o que tinha dito ao pai na caverna a respeito da mãe. Agora, ele a chama de louca, e afirma: "Ele [o pai] nunca me faria mal".

31 A simbologia na relação pessoas-animais é recorrente no filme: Olímpia (serpentes), Roxana (pantera), Zeus (águia), Héracles (leão).

${ }^{32}$ Sobre essa estratégia de Felipe, veja Worthington (2003, p. 314; 2014, p. 19, 76, 109-10).
} 
quando afirmou que "tudo começou como um mito", referindo-se à coroação de Alexandre como faraó, filho de Zeus, no Egito, e complementou: "eu sei, estava lá. Eu vi seus olhos". A estratégia, do ponto de vista narrativo, é eficiente, como disse no início. Ao mesmo tempo que o narrador pergunta se Alexandre existiu, colocando em cheque as imagens e narrativas criadas, reforça, pela existência de uma testemunha ocular, que funciona bem no cinema, pelo próprio valor da visualidade e testemunho, e por afirmações, em momentos-chave, a grandeza mítica de Alexandre, que explicaria assombrosas vitórias, como o fato de quarenta mil derrotarem duzentos e cinquenta mil em Gaugamela. ${ }^{33}$ Concluindo esta parte, como se vê, apesar de pequena, em termos temporais, a presença de Aristóteles é o momento que possibilita a questão geopolítica e a mitológica serem associadas na mente do jovem filho de Felipe, e os valores gregos de superioridade justificarem as ações de Alexandre - mesmo que, no final, a custo da moderação, por certo o conceito mais próximo da filosofia aristotélica tal como a conhecemos. ${ }^{34}$

\section{"Há trabalho a fazer. Adeus, Aristóteles." Felipe II (ALEXANDRE o Grande)}

Em 1956, foi lançado Alexandre o Grande, dirigido, escrito e produzido por Robert Rossen, tendo no papel do protagonista o já reconhecido ator shakespeariano Richard Burton. Encontramos um breve comentário (seis parágrafos) ${ }^{35}$ sobre o filme (que ele data sendo de 1955) feito por John Solomon (2001, p. 42), dizendo que o considerava o mais fiel de todos os filmes sobre o mundo antigo e talvez o mais inteligente, em parte por não se demorar em combates físicos nem por envilecer, nem glorificar excessivamente o rei macedônio. O filme traz os mais importantes episódios da vida do conquistador, relatados a partir, principalmente, de Plutarco (Vidas). No entanto, segundo o classicista, apesar de

\footnotetext{
${ }^{33}$ A representação dessa batalha crucial é controversa. Sobre a frase de Alexandre, ao iniciá-la, Winkler (2006, p. 207), por exemplo, observa que a exortação de Alexandre a seus homens, dizendo que a maior glória é morrer em luta pela sua pátria, não condiz com a finalidade da campanha de conquista de outras terras.

${ }^{34} \mathrm{Na}$ versão de 2007, Aristóteles diz que os persas eram tão cruéis que castravam os garotos para seu próprio prazer, e esta cena aparece antes de ser mostrado o mapa do mundo e de Alexandre falar sobre os mitos e as viagens. Também é introduzida uma pergunta de Heféstio, se é equivalente o amor de um homem por outro com o de um homem por uma mulher, o que o filósofo nega, devido, segundo ele, às mulheres serem escravas das paixões. Por fim, Alexandre afirma que era sonho de seu pai conquistar o Oriente, e que isso deve ser feito, ao que o mestre responde dizendo que pode apenas adverti-lo quanto a seus sonhos.

${ }^{35}$ Essa análise está inserida em um livro que tem o objetivo de dar uma visão panorâmica sobre o mundo antigo no cinema, e é seguida por um comentário de dois parágrafos sobre a tentativa de uma outra biografia, para a TV inglesa, em 1964, com William Shatner como Alexandre, dirigida por Phil Karlson. O programa piloto, de uma hora, começa com a cena da morte de Alexandre, deixando seu império, como realça Solomon (2001, p. 46), "para o mais forte". O filme piloto é comentado também por Morris (2018, p. 833).
} 
vários méritos, o filme paga o preço dessa "precisão histórica", pois não é fácil transportar "relatos literários" para "relatos cinematográficos", e o resultado de três anos de pesquisa do diretor e quatro milhões de dólares ficam comprometidos pela falta de energia dramática, evidente em muitos momentos em que, diz Solomon, "em vez de lanças são projetados discursos monótonos de Burton".

Após o lançamento do filme de Stone, junto com as análises de Alexandre surgiram algumas $\left(\right.$ poucas $^{36}$ ) de Alexandre o Grande. Se há muitas diferenças entre os dois filmes, tanto pelos respectivos projetos de seus diretores como pelos resultados, ambos partilharam de um mesmo atributo quase unânime entre os críticos: de terem falhado. ${ }^{37}$ Segundo Paul (2010, p. 28), Stone havia conscientemente tentado evitar o que ele viu como falha no filme de Rossen, a começar por evitar trazer o adjetivo "grande" no título, deixando aberto ao espectador o julgamento sobre os feitos do rei macedônio. Ademais, para Stone, Rossen havia transformado a história de Alexandre em um "drama de vingança", demorando-se muito tempo na narrativa sobre seus primeiros anos na Macedônia. Ao buscar as causas do fracasso do filme de Rossen, a partir de uma análise dos épicos que tiveram grande sucesso de público naquela época, Shahabudin (2010, p. 95-7) afirma que são necessários três elementos para um épico: "grande espetáculo, humor e vulgaridade calculada", e que o filme não atenderia a esses quesitos, porém, não sendo, também, nem historiográfico nem sucesso comercial.

Certamente os parágrafos anteriores não estimulam o leitor que não tenha visto o filme a fazê-lo. Mas há aspectos dignos de serem destacados, pelo menos em função de nosso objetivo de investigar a função e representação da figura de Aristóteles, em companhia, neste filme, de dois outros intelectuais de destaque, os oradores Demóstenes e Ésquines. Ademais, é um bom exercício de análise fílmica, a fim de compreender melhor casos singulares da história da recepção dos clássicos no cinema, que levaram críticos como Andrew Sarris a afirmar, nos Film Culture, em 1956 (apud Shahabudin, 2010, p. 97): "Rossen has aimed for greatness... but has missed honourably)". ${ }^{38}$ Mas, antes de passar às cenas que interessam, veja-se o contexto em que o filme apareceu e, esquematicamente, sua estrutura narrativa.

O roteiro do filme foi escrito por Rossen na Itália, para onde ele havia ido após sair dos Estados Unidos em 1951, por ter sido colocado na "lista negra de Hollywood", devido à filiação, que ele negava, ao partido comunista. Em 1953, ele retornou ao seu país e não apenas confessou que havia sido membro do partido por dez anos, mas também confirmou os nomes de 57 colegas membros ou simpatizantes do partido. Embora tenha voltado a obter trabalho, ele nunca mais foi a Hollywood e, como observa Shahabudin, seu filme pode ser visto como um apelo para, no contexto da Guerra Fria, promover o surgimento de uma

\footnotetext{
${ }^{36}$ Veja Wieber (2008), Fox (2010) e Shahabudin (2010), Fernández (2015b) e Blanshard (2018).

${ }^{37}$ Veja Blanshard (2018), que destaca essa apreciação já no seu título, e Shahabudin (2010, p. 94). Solomon (2010) defende que não faz sentido falar em "fracasso", nem do ponto de vista comercial, nem estético, no caso do filme de Stone.

${ }^{38}$ Vários excertos de críticas publicadas na época podem ser lidos no verbete sobre o filme na Wikipedia em inglês: https://en.wikipedia.org/wiki/Alexander_the_Great_(1956_film).
} 
sociedade mais tolerante e inclusiva. ${ }^{39}$ Por outro lado, o filme deve ser visto, também, em conexão com a recepção de Alexandre naquele momento, e, para isso, trago alguns dados com base no enriquecedor artigo de Lane Fox (historiador e consultor de Stone) sobre a peça de Terence Rattigan, que tematizou episódios da vida de Alexandre, ${ }^{40}$ Adventure Story, encenada em 1949, e que teria Richard Burton como Heféstio - papel que, segundo o ator, não foi dado a ele por Rattigan temer a possibilidade de os censores e o público verem alguma alusão à homossexualidade devido à bela aparência de Burton e do ator que fazia Alexandre. ${ }^{41}$

É oportuno lembrar que o dramaturgo inglês já havia, um ano antes, feito uma incursão no mundo clássico: destaco, aqui, a aclamada peça The Browning Version (1948), transposição de Agamêmnon, de Ésquilo, para o palco, nas terras da rainha. ${ }^{42}$ Rattigan, que se interessou pela figura de Alexandre desde criança, teve uma resposta ruim da crítica em relação a Adventure Story, embora tenha sido dito que a peça foi "a gallant failure worth a dozen so-called successes" (crítico do Daily Worker, apud Fox, 2010, p. 60), expressão que se assemelha àquela dita sobre o filme de Rossen, por Sarris (citada acima), e que será parafraseada por Stone a respeito de Alexandre. Fox se debruçou sobre as semelhanças entre os projetos e métodos nas obras de Rattigan e Stone, bem como a recepção pelo público em um artigo iluminador. Não vem ao caso apresentar, aqui, essa cuidadosa análise. Interessa-me apenas apontar para a existência da peça de Rattigan, sete anos antes do filme de Rossen, e a influência de Werner Jaeger - cuja monografia Aristóteles, lançada em 1948, impactou sobremaneira, segundo Fox (2010, p. 67-70), o modo como o filósofo foi representado no processo educativo do protagonista de Rattigan -, exemplificando as interações entre as pesquisas acadêmicas e produções artísticas que as utilizam e popularizam.

Postas tais circunstâncias, vamos ao enredo do filme. A primeira imagem é de uma medalha que parece um molde de uma moeda antiga, na qual Alexandre foi retratado como Héracles, com a pele de leão sobre a cabeça, em um fundo azul. ${ }^{43}$ Após esse retrato simbólico, (re)conhecido por muitos, segue uma frase falada por Burton, em voz off: "It is

\footnotetext{
${ }^{39}$ Para mais informações sobre o tema, veja Shahabudin (2010, p. 102-5) e Wiener (2008, p. 150). Fernández (2018a, p. 417) fornece alguns dados sobre motivações pessoais que teriam influenciado Rossen, principalmente na relação entre Felipe e seu filho (em entrevista, o diretor fala sobre o contato entre seu pai e seu avô), mas não toca em nada relevante para minha questão. Naturalmente, uma série de comentários e explicações do autor não sustentam sua obra, que precisa se fundar sobre si mesma, embora eles possam ter algum valor como complemento para se entender certas decisões. ${ }^{40}$ A influência de Rattigan sobre Stone é indireta, por meio da representação da escritora Mary Renault, que lera o dramaturgo britâncio e cujas obras, The Nature of Alexander, biografia de 1975, e o romance histórico de 1972, The Persian Boy (sobre Bagoas), seriam de conhecimento de Stone.

${ }^{41}$ Naturalmente, naquele ambiente homofóbico, Bagoas poderia aparecer. A peça foi levada para a TV britânica em 1961, com Sean Connery no papel de Alexandre. Fox cita outra peça sobre Alexandre, de Nathaniel Lee, Rival Queens, de 1670, e Mossé (2004, p. 198), entre as várias peças teatrais sobre o jovem conquistador, comenta a de Racine, Alexandre, encenada em 1665.

${ }^{42}$ Levada duas vezes para o cinema, em filmes homônimos, por Anthony Asquith (1951) e Mike Figgis (1994). Sobre o tema, veja Coelho (2009).

${ }^{43}$ Sobre imagens de Alexandre em moedas, veja Moreno (2012).
} 
men who endure toil and dare dangers that achieve glorious deeds. And it is a lovely thing to live with courage and to die leaving behind an everlasting renown." ${ }^{44}$ Em seguida, sobre ela, os créditos. Mudando para um prédio em ruínas, a informação de que o ano é 356 a.C., em uma Grécia dividida e problemática. Após uma primeira sequência com Demóstenes (Michael Hordern) argumentando contra Ésquines (William Squire) sobre a necessidade de as cidades gregas se defenderam contra Felipe II (Fredric March), o rei macedônio, a paisagem muda. Felipe é mostrado, em campo de batalha, recebendo a notícia do nascimento de seu filho, o que lhe causa apreensão, pois havia acabado de ter um sonho perturbador, além de não confiar na fidelidade de Olímpia (Danielle Darrieux). Posteriormente, ao lado dela e próximo do pouco confiável adivinho Nectanebo (Helmut Dantine) ${ }^{45}$ ele é persuadido por Parmênio (Niall MacGinnis) a reconhecer o filho, que irá, após outra mudança de cenário, ser mostrado já adulto, entre as atividades físicas e as lições de Aristóteles (Barry Jones) em Mieza. Enviado para reinar em Pela, onde está sua mãe, Alexandre posteriormente se junta a Felipe, salvando-o da morte na batalha de Queroneia. No entanto, o relacionamento entre eles se deteriora após o divórcio de seus pais e o casamento de Felipe com a jovem Eurídice (Marisa de Leza), que leva Alexandre a ser visto como bastardo.

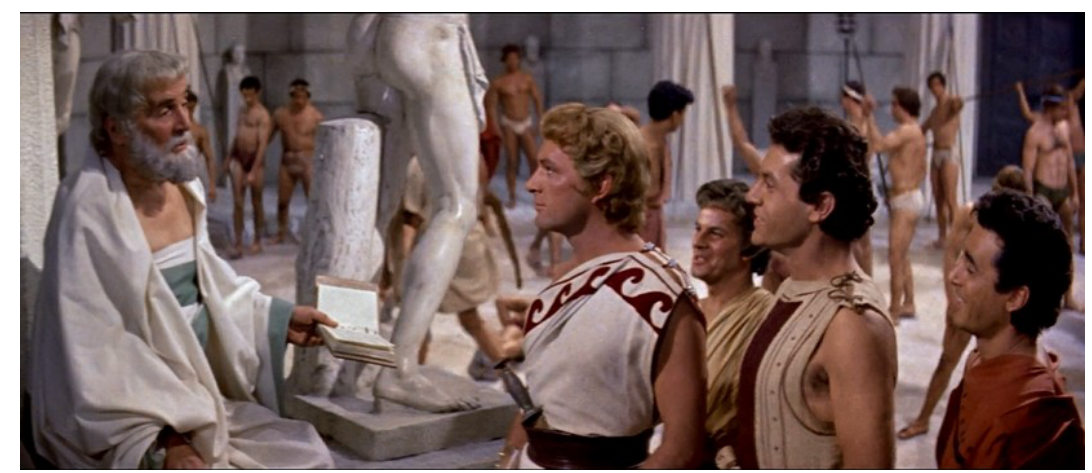

FIGURA 2 - Alexandre o Grande: Aristóteles, com Alexandre e outros alunos

Felipe é assassinado por Pausânias (Peter Wyngarde), que logo em seguida morre pelas mãos de Alexandre - uma cena ambígua, pois impossibilita o esclarecimento de quão Olímpia e seu filho estavam envolvidos no assassinato, sendo eles próximos a Pausânias. Coroado rei, Alexandre parte para sua conquista, e, ao vencer batalhas como a de Granico, mostra a Dario (Harry Andrews) que ele era mais do que "um garoto" e, ao longo das conquistas, mostra sua habilidade com situações lendárias, como o episódio do nó górdio. ${ }^{46}$ Atendendo ao pedido do rei persa, assassinado por ex-aliados, Alexandre se casará posteriormente com

\footnotetext{
${ }^{44}$ Encontrada em Arriano.

${ }^{45} \mathrm{Na}$ Vida de Alexandre $(\mathrm{I}, 7)$, ele aparece como profeta que teria dormido com Olímpia e gerado Alexandre.

${ }^{46}$ Não aparece em Stone, que preferiu usar a doma de Bucéfalo, episódio mais cinematográfico, para mostrar o caráter de seu Alexandre, considerando a representação heroica de cavalos em tantas culturas.
} 
sua filha Roxana (Teresa del Río), em Susa, embora tenha, como companheira, Barsine (Claire Bloom), persa criada na Grécia e mulher de Menon (Peter Cushing), um dos aliados de Dario. Em uma cena que reverbera a inicial, o orador Ésquines, após saber da chegada de Alexandre à Índia, reconhece o perigo para os gregos de Alexandre ter "superado os deuses”, fato desalentador para Demóstenes. Posteriormente, após matar seu amigo de infância Clito (Gustavo Rojo), afetado pela bebida e cercado por outros amigos de infância, como Ptolomeu (Virgílio Teixeira) e Heféstio (Ricardo Valle), ${ }^{47}$ Alexandre decide retornar, e um trecho desse retorno, entre Índia e Babilônia, é narrado por Ptolomeu, que conclui ter sido acertada a decisão, fruto de uma compreensão de Alexandre de que "não são terras que devem ser conquistadas, mas o coração dos homens". É neste momento que ocorre a celebração coletiva em que vários gregos desposam mulheres persas, como símbolo de união entre bárbaros e gregos, e ele se une com Roxana. ${ }^{48} \mathrm{Um}$ pouco antes de falecer, deixando seu reino "para o mais forte". Nesta cena, ele está cercado por generais, além de Roxana e Barsine, a quem pede para seu corpo ser jogado no rio, para que, desaparecendo, mantenha a lenda de sua origem divina. A última frase é de uma voz em over citando a famosa passagem do coro de Antígona "Wonders are many - but none is more wonderful than man himself", frase que havia sido dita por Aristóteles durante sua lição, enquanto a câmera se movimenta mostrando um céu azul, sobre o qual é projetada a mesma imagem que abrira o filme, 136 minutos antes.

Começando pelo fim, é oportuno fazer um comentário sobre a frase dita por Aristóteles e escolhida para encerrar o filme, que começou com uma frase de Alexandre (segundo Ariano). Colocar Aristóteles citando Sófocles é algo muito plausível, mas encerrar o filme relembrando a frase dita para um jovem e impulsivo Alexandre é algo não apenas provável, mas muito significativo na construção da figura do futuro rei e da influência do filósofo sobre ele. É importante notar que a famosa sentença está nos versos iniciais do segundo canto coral (= primeiro estásimo) da peça de Sófocles (Ant. 332-75), lembrando que no primeiro canto coral é louvada a vitória dos tebanos contra os argivos, vistos como invasores, ainda que liderados por Polinices. Na tradução de Jaa Torrano, atento à complexidade do termo-chave deinos nos seus sentidos positivo e negativo (terrível, admirável) - "Muitos os terrores e nenhum mais terrível do que o homem" -, pode-se encontrar um caminho para a interpretação do papel do filósofo na estrutura do filme. Veja-se a representação do encontro entre Aristóteles e Alexandre, digamos, em close up.

Em primeiro lugar, ela não é verossímil, pois Richard Burton nos seus 30 anos não é convincente como um rapaz de 14 (se dermos importância a um dado histórico, algo tão elogiado no filme). Mas releve-se esse detalhe e observe-se a interação entre discípulo e mestre.

\footnotetext{
${ }^{47}$ Fox (2010, p. 63) analisa como, em 1948, Tarn apagou a inconveniente presença de Bagoas da história, opção também de Rattigan e Rossen. Deve-se notar, ainda, que a presença de Heféstio nessas duas obras não sugere nenhum afeto que pudesse ferir a sensibilidade do público conservador.

${ }^{48}$ Worthington (2003, p. 43) argumenta que os motivos para esses casamentos não eram ideológicos, mas político-militares, visando também à integração de estrangeiros no exército e nas atividades administrativas.
} 
Da cena de Felipe levantando o recém-nascido nos braços, com pessoas aplaudindo, em um cenário na entrada do palácio, que mostra estátuas de leões semelhantes aos da passarela de Delos, há um corte para uma escultura, vista em contre-plongée, com o azul do céu como fundo, e o deslocamento da câmera para uma cena de exercícios de jovens na palestra. Em seguida, temos a primeira aparição de Alexandre, como adulto, chegando a cavalo de uma caçada, entregando o animal aos jovens que treinam uma luta, em espaço contíguo ao que está Aristóteles, que, sentado, lendo, recebe o discípulo que o cumprimenta. Ao perguntar quem caçou o animal e ser informado que Alexandre o fez, sozinho, a pé, em uma cena semelhante a um duelo em disputa por um reino, Aristóteles afirma: "Não haveria necessidade de tal duelo." Em seguida, ele informa a Alexandre que Clito retornou e, em seguida, temse o diálogo entre os amigos Clito e Alexandre, em que é narrada a vitória de Felipe, além do Bósforo, e o saque de algumas cidades. Aristóteles, ouvindo, comenta surpreso: "Um exército grego em solo persa; o sonho da Grécia por mais de 200 anos e a glória vai para Felipe. Salve, Felipe!” Alexandre repete, com visível desgosto a saudação, e depois, ao saber que o seu pai não o quer nas novas tropas a serem enviadas para a guerra, afirma, irado, após ouvir Aristóteles dizer que Felipe visa ao bem do filho: "Ele tem a glória e nós ficamos com Aristóteles e suas maravilhas da ciência, da matemática, da história e da lógica. E talvez algum dia algum de nós escreverá um livro e ficará conhecido como o pupilo de Aristóteles."

No entanto, imediatamente após sair e começar a treinar arremesso de disco, ele, ao ver Aristóteles entrando, pede perdão pela fala ofensiva, ouvindo, porém, de seu mestre: "Mas por quê? Você falou como um rei. E eu como um professor", ao que Alexandre responde: "E como um amigo". Sentados, eles conversam sobre as batalhas na Ásia. Aristóteles vê esse momento como uma possibilidade de os gregos se unirem e acabarem com as lutas intestinas, derrotando a Pérsia. Mas ele teme que Felipe, visto como bárbaro pelos gregos (isso se confirma por uma cena posterior em que Felipe, bêbado, dança e imita Demóstenes, que o chamara de bárbaro), não consiga governar e trazer a concórdia para todos. Essa "missão sagrada" de destruir a Pérsia seria para Felipe, mas Aristóteles teme que ele não consiga realizar isso. Vale a pena transcrever o diálogo que se segue:

Aristóteles: Você sabe o quão vasto é o Império Persa?

Alexandre: Do Nilo, ao Indo, de Samarcanda à Babilônia.

Aristóteles: É além. Você sabe quantas pessoas diferentes vivem lá? Alexandre: De cor. Carianos, armênios, judeus, partos, egípcios. Conheço seus costumes e seus deuses.

Aristóteles: Sim. Mas isso é mais do que um império, isso é colosso. Para governar, seria preciso um homem tão bom quanto você pode ser. E por isso que digo "Paciência".

Alexandre: Paciência? Meu tempo é curto.

Aristóteles: Curto?

Alexandre: Quando o grande deus Zeus, pai de Aquiles, lhe deu a escolha de uma longa vida de obscuridade e uma curta vida cheia de glória, ele escolheu a glória. Eu também. Aquiles morreu jovem... 
Neste momento, Aristóteles sugere que ele vá ficar com seus amigos, que o esperam. Curiosamente, começa uma cena em que são mostrados jovens se exercitando ao ar livre, rodeados por estátuas, realçando seus corpos (algo semelhante ao estilo de Leni Riefenstahl). A cena é interrompida com outra, do filósofo olhando para a câmera (como se fosse uma parábase na comédia grega), dizendo (ao espectador) "Nós, gregos, somos os escolhidos, os eleitos. Nossa cultura é a melhor, nossa civilização, a melhor; nossos homens, os melhores". A imagem dos soldados se exercitando retorna, e o instrutor deles diz “Olhem!", e a voz em off de Aristóteles continua: “Todos os outros são bárbaros! E é nosso dever moral conquistálos, escravizá-los e, se necessário, destruí-los!’” ${ }^{49}$ Em seguida, se dirigindo a Alexandre e seus amigos, ele diz:

As maravilhas são muitas - mas nenhuma é mais maravilhosa que o próprio homem. O modo de vida persa tem a semente da morte e o medo. A do grego, da vida e coragem [aqui voltam as cenas de lutas e a narrativa em off]. Os deuses dos gregos são feitos à imagem dos homens - não homens com cabeças de pássaros, bois e leões, mas homens que podem ser entendidos e sentidos.

Segue, a esta cena, uma leitura em voz alta de Alexandre de uma passagem da Ilíada, cercado pelos seus amigos. A escolha desse trecho é indicativa, a meu ver, do desejo de um jovem pelo prazer da luta em si e da conquista, mais do que dos ideais políticos de Aristóteles. Sem dúvida, essa passagem é compatível com a frase de abertura, que Burton cita, enfatizando a ousadia guerreira: ${ }^{50}$

Alexandre: [citando o canto 20, 498-503, da Iliada] ${ }^{51}$... assim os cavalos de casco não fendido do magnânimo Aquiles/ pisaram tanto cadáveres como escudos, com todo o eixo do carro/ salpicado de sangue por baixo e os rebordos do carro,/ pois saltavam contra eles os salpicos das patas dos cavalos/ e das rodas. Porém, o Pelida continuou em frente para obter/ a glória, e de sangue estavam borrifadas as suas mãos invencíveis.

A presença explícita de Aristóteles no filme termina com Felipe, após oferecer o reinado ao filho, que, contra o desejo de Aristóteles, que vê uma sobrecarga nas costas de um

\footnotetext{
${ }^{49}$ Veja notas 25 e 26.

${ }^{50}$ Morris (2018, p. 832) observa como Arriano, na descrição da vida de Alexandre, focaliza nas cenas de batalha e nos temas da guerra, algo que podemos destacar neste filme, que encena várias das batalhas na carreira de Alexandre.

${ }^{51}$ Uso, aqui, a tradução de Frederico Lourenço, lembrando que no texto grego de Homero está o termo megalothumos, traduzido, aqui, por "magnânimo", quando talvez fosse mais apropriado "de grande ímpeto" ou "coragem", pois "magnânimo" seria, em grego, megalopsychos, conceito fundamental para a concepção ética de Aristóteles, discutido na Ética a Nicômaco (IV, cap. 3). No filme, em inglês, é dito "great heart".
} 
"garoto", aceita imediatamente, dispensando os serviços do filósofo, dizendo: "Há trabalho a fazer. Adeus, Aristóteles". Seguem, então, as palavras finais do estagirita, enquanto a câmera mostra o busto de Alexandre, em contre-plongée, com um olhar altivo e uma música triunfante: "Adeus - e leve essas palavras com você e use-as para o que elas valem: Alexandre é muitas coisas. Ele é lógica; ele é sonhos. Ele é guerreiro e poeta. Ele é homem, e espírito. Ele é seu filho, mas ele é dela, também, e ele acredita ser um deus".

Creio que os longos trechos acima revelam claramente o uso da figura de Aristóteles para justificar as ações de Alexandre, como, também, a intenção do diretor, ao repetir o trecho sofocleano no final do filme. Se, como alegou Shahabudin, Rossen levou a história para a tela, em um momento da Guerra Fria em que ele queria passar uma mensagem de uma união da humanidade, outros aspectos do discurso atribuído a Aristóteles (que, historicamente, não seria compatível com seus escritos), como a conquista e o domínio da Pérsia, parecem estar a serviço de uma visão imperialista. Por outro lado, considerando que o filme termina com o casamento em Susa unindo gregos e bárbaras, pode-se pensar que as lições de Aristóteles não foram seguidas. Nesse sentido, o filme tem muitas ambiguidades. Quando Alexandre havia se encontrado com Barsine pela primeira vez, havia lhe dito que seu pai chamava Atenas de uma ideia, não um lugar, e que Aristóteles o ensinou que uma ideia é maior que um homem. O final quer fazer crer que a ideia que prevaleceu não foi a da conquista, da escravidão ou da destruição dos bárbaros, mas a da assimilação e da união. Filme-se a lenda. ${ }^{52}$

\section{“TUdo É PERMitido NA GUERRA E NO AMOR." Alexandre (Sikandar)}

O mais antigo e menos conhecido dos filmes sobre Alexandre é Sikandar (1941, Índia), de Sohrab Modi, interessante não apenas porque o protagonista é retratado pela perspectiva dos conquistados mas pela construção, muito significativa e diferente da habitual, das personagens de Aristóteles e Roxana. Embora seja um filme importante no âmbito da produção indiana e de um renomado diretor, ele não é comentado ou mesmo citado por praticamente nenhum pesquisador. No livro de Cartledge e Greeland, não há dele uma referência sequer (e sobre a figura Poro há poucas referências). No mais recente Companion to Alexandre, da Brill, ele é citado por Alexandra Morris (2018) ${ }^{53} \mathrm{em}$ um comentário no

\footnotetext{
${ }^{52}$ Como mostra Worthington (2003, p. 314-5), casamentos não foram propostos entre mulheres macedônias com homens persas, e o divórcio entre os casamentos em massa em Susa após a morte do rei mostra que foram, certamente, forçados por uma política pragmática, visando aproveitar o conhecimento da língua e do local a favor dos macedônios, tendo estado sempre nas suas mãos o controle do exército e do tesouro.

${ }^{53}$ Ao analisar o tratamento dos desabilitados e o ethos de Alexandre, inclusive de seu meio-irmão Arrideu, Morris nota como os filmes excluem representá-los, exceto em Sikandar. Ela destaca, aqui, as diferenças culturais entre Ocidente e Oriente, comentando que ainda nos anos de 1940, na Índia, os desabilitados que voltaram para casa tinham um tratamento digno e eram bem recebidos, após a batalha com Poro, mesmo que os dois não fossem representados. A cena é mostrada enquanto uma
} 
contexto do tratamento dado por Alexandre aos desabilitados e feridos, nos relatos, literários e cinematográficos. Blanshard, no mesmo Companion, ao analisar o filme de Rossen, não faz nenhuma referência a ele. Por sua vez, Anja Wiener faz um breve comentário sobre Sikandar, na parte de seu artigo que ela chama "Beyond Hollywood", na qual entram todas as representações que estão fora do mainstreen cinema no qual incluo aquele de Stone e de Rossen. Dois artigos dedicados ao filme foram escritos por Jordi Fernández (2015a, 2015c), quando doutorando em história de uma universidade francesa. Como se vê, essa produção periférica (pensando no domínio cultural internacional da indústria cinematográfica americana, mesmo levando em conta o peso da indústria indiana) tem também uma apreciação produzida, pode-se dizer, na periferia das publicações das grandes editoras.

Sikandar foi lançado pela Minerva Movietone, estabelecida em 1936 por Sohrab Modi, diretor, produtor e também ator, com incursões por um cinema preocupado com temas sociais como divórcio e alcoolismo. Modi tinha formação no teatro Parsi, tradição que floresceu no Norte da Índia entre 1850 e 1930, começando com adaptações de Shakespeare, mas depois introduzindo temas nacionais. Em um artigo encomiástico, dele foi dito: "if there is to be an equivalent of a 'statesman' in the world of Hindi movies, it will undoubtedly be Sohrab Modi, the man blessed with tremendous foresight, phenomenal perseverance and remarkable courage, who stood on the forefront when foundation of film making was being laid in India." ${ }^{54}$ Falado em Urdu, Sikandar possui roteiro e canções de Pandit Sudar Shan e trilha sonora de Rafiq Ghaznavi e de Mir Saheb, que é fundamental na estrutura da narrativa, com números musicais aparecendo em vários momentos (como não poderia faltar em um filme indiano!) que talvez sejam estranhos para o gosto ocidental em um filme épico. No entanto, essa abordagem romântica e musical da cultura indiana não impede sua forte mensagem política, seu pacifismo e crítica ao Ocidente. ${ }^{55} \mathrm{O}$ fato de o filme ter sido censurado, devido a seu tema nacionalista (Alexandre pode ser visto como uma alegoria do Império Britânico) em um momento no qual a Índia lutava por sua independência e Gandhi pregava desobediência civil, indica isso. Sikandar chegou a ser banido de alguns cinemas e de algumas áreas militares inglesas em que indianos serviam. Segundo o mesmo

mulher canta uma canção que fala da alegria de receber de volta seu marido, tendo a guerra acabado. No filme de Stone não aparecem Arrideu ou Harpalus como personagens; no de Rossen, Felipe é manco, mas tem os dois olhos, e Harpalus não tem nenhum problema físico. A presença deles e o tratamento cuidadoso por Alexandre poderia realçar seu caráter generoso, mas isso não é feito. $\mathrm{O}$ assassinato dos desabilitados no filme de Stone, em uma abordagem foucaultiana da autora, é visto como traço de uma sociedade industrializada, algo que não havia ocorrido na Índia na época de Sikandar. A compaixão de Alexandre, citada por historiadores, principalmente Curtius Rufus, vai de encontro à orientação de Aristóteles de expor crianças deformadas para morrerem como é inferido da Constituição Ateniense, 49, 4; Pol. 1335b, em que diz que deveria ter uma lei proibindo que crianças deformadas fossem educadas, o que significa que eram, já que ele sugere que não - sobre o tema, veja Morris (2018, p. 831).

${ }^{54}$ Malhotra (2011).

${ }^{55}$ Coelho (2012), Fernández (2015a). 
artigo, para a realização do filme - muito superior aos do mesmo gênero produzidos na época, com notável direção de arte e figurino -, foi fundamental a parceria do ator que interpretou Alexandre, Prithviraj Kapoor, que teve, ali, um de seus maiores papéis, notável por seu estilo e linguagem corporal. A cinematografia de Y. D. Sarpotdar foi reconhecida com louvor, principalmente nas grandes cenas de batalhas, com elefantes entre homens e cavalos, sem efeitos especiais. Um sucesso de bilheteria, o filme foi dublado em persa, e refilmado, em 1965, como Sikandar-e-Azam, dirigido por Kedar Kapoor, e com Prithviraj Kapoor fazendo o papel de Poro. ${ }^{56}$

A ação de Sikandar, nos seus 143 minutos, começa “em um dia em 327 a.C., quando a bandeira grega estava desfraldada sobre o Irã”. Alexandre, após conquistar a Pérsia, se aproxima da fronteira da Índia, em Jhelum, onde, em seguida, irá vencer o rei Poro (interpretado por Modi), episódio famoso na campanha indiana. ${ }^{57}$ Apaixonado por uma jovem iraniana, Roxana (= Rukhsana, interpretada pela excelente Vanamala), ele é orientado por Aristóteles (Shakir) a ter cuidado com as mulheres (algo que no filme de Stone é dito por Felipe, mas, ali, pensando em Olímpia). Roxana, que procura convencê-lo das teorias equivocadas de Aristóteles sobre a mulher e o amor, busca protegê-lo e o segue, escondida, até a Índia, onde se encontra com Poro, e se torna sua irmã pelo ritual de "rakhi" (fita amarrada ao pulso estabelecendo laços de proteção entre parentes, aqui simbolizando, para Poro, a união entre Irã e Índia). Com isso, ela consegue do rei a promessa de não matar Alexandre, com quem ela se reencontra no final. Após a famosa batalha, a nobreza de Poro, que perde um dos filhos na batalha, impressiona Alexandre. O diálogo entre os dois e seus códigos de honra lembram a nobreza entre inimigos do famoso filme de Jean Renoir, $A$ grande ilusão (1937).

Passemos ao filme, que começa com uma cerimônia com uma triunfal entrada de Aristóteles, chegando em um carro e saudado pelo exército, depois visto em close-up, para uma cerimônia na qual Alexandre não comparece. Surpreso, ao ver a cadeira do rei vazia, o filósofo pergunta a Seleuco (Lala Yakub) se sabe a razão de o rei faltar a compromissos tão importantes nos quais negócios de estado serão discutidos, e, irritado, cancela o evento público, apesar de os militares estarem ansiosos por ouvir as proclamações de Aristóteles. A cena se transfere para o palácio, uma longa e romântica sequência entre Alexandre e Roxana, que começa com ela pedindo a ele que pronuncie seu nome corretamente "Rukhsana", e não "Rexrees", ao que ele responde que, quando gosta de algo, muda os nomes para o grego. Ela

\footnotetext{
${ }^{56}$ Sobre o nacionalismo do filme de Modi, veja Pothukushi (2019). Sobre a versão de Kapoor, Wine (2008, p. 161) comenta que suas canções ainda eram, em 2008, tocadas nas rádios indianas. A versão de 1965 está acessível no Youtube, mas sem legendas, e nela a figura de Aristóteles empalidece sobremaneira. ${ }^{57}$ Sobre o aspecto espetacular e exótico da vitória sobre Poro, Bosworth (1995, p. 130) nota como, após essa vitória, foram cunhadas tetradracmas com imagem de seus inimigos: de um lado, um elefante, de outro, um arqueiro indiano. Posteriormente, foram cunhadas decadracmas com Alexandre a cavalo, com uma sarrisa, e um elefante. Se a vitória foi completa e exótica, por outro lado, como toda propaganda, ela minimizou as grandes perdas entre os macedônios. Sobre a admiração e o contato de Alexandre com Poro, veja Bosworth (1995, p. 130-9) e Worthington (2003, cap. 6).
} 
pergunta então sobre o nome dele, e recebe a resposta: "Em Grécia eu era Alexandre, mas o Irã me fez Sikandar." 58 Cenas como esta, aliadas a outras em que ele diz "olhe para meus olhos atraentes com seus olhos atraentes" dão um tom cômico à figura do rei, um galante conquistador em armadura de guerra. O idílio é interrompido por Aristóteles, recebido com uma prosquínese de Alexandre (mais ironia!?). O mestre informa ter ido visitar o discípulo apenas para dizer:

Se quer conquistar o mundo, deve vencer sua mente e se deseja isso, deve ficar longe de mulheres [aqui em close up]. O que se envolve no mundo das mulheres é destruído. Isso não é algo que criei, é a lição da história. O que segue minhas palavras viverá a vida imortal do soldado, o que não, viverá na escuridão, e morrerá anônimo.

Roxana, que saíra, antes de Aristóteles entrar, para buscar uma guirlanda que havia feito para o amado, ao ficar sabendo do que ocorrera, preparará uma prova para mostrar que a mulher não é a "maior fraqueza do homem, mas sua maior força", desafiando o próprio amado, que diz ser um grande rei, mas que, perto de Aristóteles, "não passa de uma criança", complementando "Se Aristóteles quiser, pode fazer mil Alexandres, mas o contrário é impossível." Ao recusar o vinho oferecido por Roxana e repetir mais palavras do mestre, perguntando o que ela acha delas, ele ouve: "Aristóteles insultou e desprezou o papel da mulher e sua maturidade. Ele, que pensa que está acima de todos, receberá a resposta de uma insignificante mulher, e terá a reputação destruída pelo olhar de uma."

Embora Alexandre duvide da capacidade de Roxana vencer seu mestre, ele aceita o plano e se esconde para ver o que ela promete, baseada na premissa de que "Aristóteles é homem e tem um coração", por sua vez questionada por Alexandre, que diz que "se ele teve um alguma vez, esse já está morto”. Em seguida, em uma cena musical, a princesa canta uma música sobre o despertar da juventude e da beleza, sob a janela de Aristóteles, que, encantado, desce para o jardim e faz galanteios a Roxana dizendo ser ela a "personificação do conto de fadas, o sonho que a humanidade busca, a história que a primavera canta no ouvido das flores" etc. Ele fala sobre uma jovem grega que amou, e cuja morte o transformou em um velho. Perguntado se o oposto poderia ocorrer, o filósofo diz que o velho se torna jovem quando encontra o amor. Em uma mudança repentina, pergunta se ela seria capaz de amá-lo e afirma que dará tudo o que ela pedir. Ao ver seu sorriso de desdém, ele diz que ela só pensa em aparências, e não no coração. Então, Roxana muda e pede algo, dizendo apenas para ele, no pé do ouvido. Dando um sinal para Alexandre, escondido, ela se mostra cavalgando em Aristóteles, que, com um véu servindo de rédea, se comporta como um cavalo, trotando em volta de uma fonte. Quando Alexandre entra na cena, o filósofo se desculpa, mas o estratagema de Roxana é interpretado por ele como um alerta para o rei: "se uma mulher pode fazer de tolo um velho sábio, imagine o que fará com um jovem?" Após mais lições sobre a impaciência e paixão dos moços, o filósofo sai. Roxana, apesar

\footnotetext{
${ }^{58}$ Esta tradução e todas as que se seguem são minhas, da legenda em inglês.
} 
de arrependida, após o comentário de Aristóteles, ainda defende que amor e paz, e não a guerra, devem nortear a vida, após ouvir do amado "Eu sou seu, você é minha, mas até eu conquistar a Índia, não aparecerei diante de ti." Saindo do jardim, após subir as escadas, Alexandre se vira e faz a famosa "salute romana", o que é bastante significativo e perturbador em um filme contemporâneo à Segunda Guerra. Na cena seguinte, Aristóteles, ao se despedir do rei dizendo "seu objetivo é conquistar o mundo. Vá em frente, nós voltaremos", ouve, como resposta: "mas precisarei de seu conselho em cada passo do caminho". Em retorno, o filósofo diz: "Já lhe dei tudo que precisava, mas você precisa saber o que uma mulher é capaz de fazer a você. Tenha fé nos deuses. Todos os países do mundo estão esperando para aceitar você como seu líder." 59

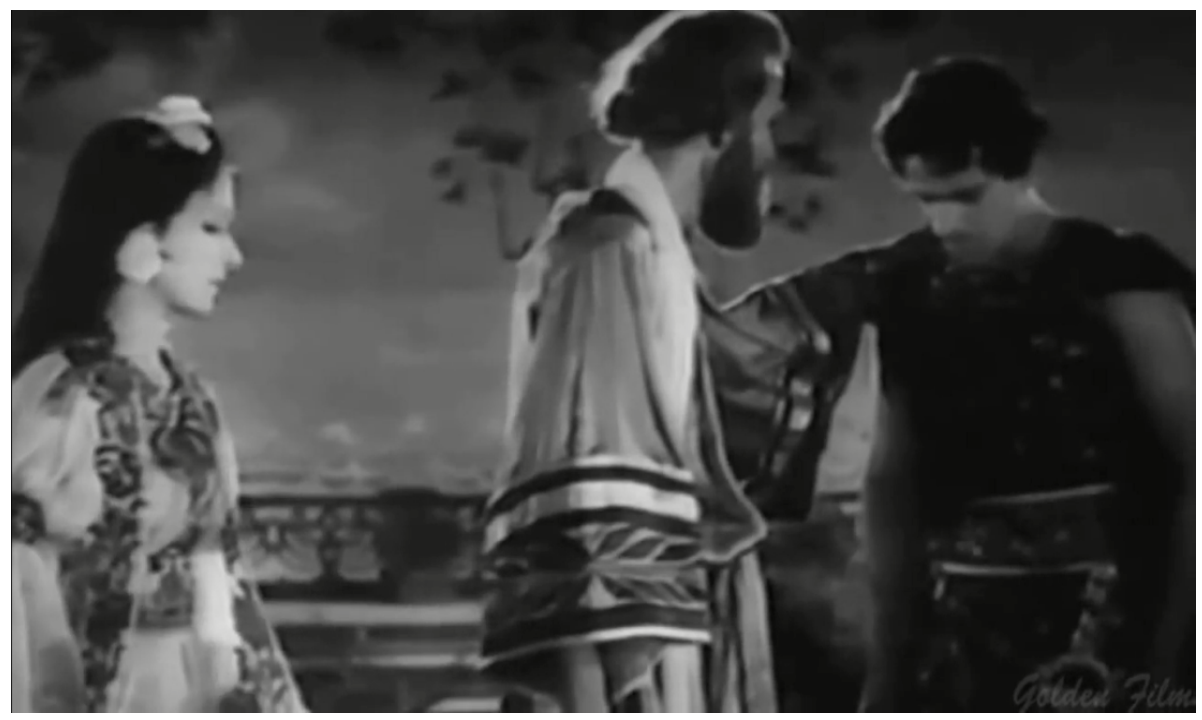

FIGURA 3 - Sikandar: Aristóteles, com Alexandre e Roxana

Entre a partida de Alexandre e o reencontro com sua amada, derrotado, temos os episódios com Abhir aliando-se aos macedônios, Poro reunindo os príncipes para defender a Índia contra o invasor, a ida de Alexandre, disfarçado de mensageiro, para falar com Poro - que mesmo descobrindo o estratagema não mata ou prende o rei macedônio - e a andanças de Roxana para proteger seu amado, além das grandes cenas de batalhas, tudo isso entremeado com muitos números musicais, inclusive pelos soldados gregos, que, enquanto cavalgam, cantam "a vida existe por causa do amor". A perspicácia de Roxana e sua firmeza em interagir com os indianos é notável. Ao lado dela, outra personagem feminina de destaque é Parthana (Meena), irmã do rei Ambhi (K. N. Singh), a quem não poupa duras críticas por

${ }^{59}$ É muito interessante observar que há duas versões disponíveis na rede, sem versão em inglês, e, em uma delas, as cenas de Aristóteles com Roxana cavalgando são excluídas. Veja https://www.youtube.com/watch?v $=\mathrm{Cr} 8 \mathrm{~S} 5 \mathrm{~Wb} 3 \mathrm{O}-\mathrm{s}$, de $2 \mathrm{~h} 21$, e a versão na qual houve a exclusão: https://www.youtube.com/watch?v=PL5hvaBgD0o, de $2 \mathrm{~h} 04$. 
ele ter se aliado aos macedônios, contra o povo indiano, em sua luta pela liberdade. Não concordando com essa traição antinacionalista, ela o abandona, rompendo a relação de irmandade, e vai para o palácio de Poro, elogiada por sua bravura e desprendimento em lutar pela liberdade da Índia. ${ }^{60}$ Antes, porém, ela conta a fábula da briga entre o cavalo e o leão, na qual o primeiro, vendo-se em desvantagem, aceita a oferta de um homem que pediu que ele o deixasse montar, e daí em diante, nunca mais deixa de servir a este homem - fábula esta interessante se pensarmos que pode ser vista também como reverberação da cena de Roxana e Aristóteles, e do significado simbólico da vergonha do dominado.

Voltando a Roxana, Alexandre e Aristóteles, o filósofo, segundo o filme, estava certo ao dizer que a mulher poderia destruir o homem. É Roxana que, em um discurso inflamado, insufla nos soldados gregos o desejo de voltar para casa e para a guerra. Após o motim, Alexandre, preocupado com o que dirão dele os livros de história, pede um sacrifício ao seu pai Zeus. O sacrifício não é benéfico, o que faz Alexandre desistir de lutar e voltar para Babilônia, mas nesta cena Roxana já se reúne com ele e o consola. Assim termina o filme, em que a astúcia da mulher vence, tendo a paz como fio condutor com o qual ela costura sua vida à vida de Alexandre, em uma cerimônia ali mesmo onde se casam. Destarte, Modi contraria a visão aristotélica ali apresentada, uma derrota para o filósofo imperialista e uma vitória para o rei, lembrando que, no filme, por ordem de Alexandre, os filhos de Modi e Abhir também se unirão em matrimônio e, no final, todos, indianos e gregos (enquanto remam e cavalgam), cantam "a vida existe por causa do amor".

Antes de encerrar, creio ser oportuno comentar essa versão do encontro de Roxana com Aristóteles, no qual ela o doma como um cavalo. Versão similar a essa, que torna esse filme tão peculiar pela referência a esse famoso episódio, aparece, entre nós, no famoso Orto do Esposo, texto de um monge anônimo português, escrito entre os séculos XIV e XV. ${ }^{61}$ O teor do livro é o desapego dos prazeres e dos bens mundanos, em favor do ascetismo e da contemplação. ${ }^{62} \mathrm{O}$ texto é ilustrado por exempla, e a visão misógina e moralizante é uma constante; sendo o "esposo" a figura de Jesus Cristo, esse horto é repleto de prazeres espirituais. Há histórias sobre mulheres pecadoras e santas - entre elas está a da mulher de Alexandre, exemplo da mulher que busca a vingança, no caso, contra Aristóteles, que sugeriu ao rei evitá-la, como diz o texto "Aristotelles, o grãde philosoffo, "sinava e castiguava rey Alexandre que se nõ ajuntasse ameude a sua molher [...]" transcrito por Bertil (1956, p. 153-4). É ali que se encontra esse relato que é o mesmo do filme de Modi, mostrando

\footnotetext{
${ }^{60}$ Sobre vários aspectos, da crítica à idealização da figura de Alexandre, e as conexões de passagens do filme com a política e cultura indiana, veja Fernández (2015c), que concentra sua análise na interação entre os dois reis. Note-se que episódios famosos como a morte de Bucéfalo por Poro são minimizados. Assim que seu cavalo morre, Alexandre monta outro e continua a luta.

${ }^{61}$ Impresso pela primeira vez em 1956 por Bertil Maler, com edição crítica, possui uma outra posterior de Irene Freire Nunes, de 2007, ambas a partir de dois manuscritos alcobacenses da Biblioteca Nacional de Lisboa. Veja Esteves (2014) e Ayres (2017).

${ }^{62}$ Aliás, Alexandre é citado várias vezes no livro. Aqui, o relato está inserido no capítulo sobre o perigo dos olhos e do desejo provocado pelo olhar.
} 
quão complexos são os caminhos da recepção. ${ }^{63}$ No texto, ela desce até o horto onde ficava o filósofo, mostra as pernas e anda descalça, e, por fim, após seduzi-lo, um dia "a raynha cavalgou sobre ele. E estando ele - pees e - maaos, sobreveo Alexandre". Voltando ao filme de Modi, vemos nele o uso de outras fontes para falar de Aristóteles em sua relação com Alexandre; no entanto, algo permanece na construção do rei macedônio, apesar de seu apreço pelo mestre. A sua desobediência a certos preceitos filosóficos, incompatíveis com seu pothos, seja pela guerra, seja pelos prazeres.

\section{ConsideraçõEs FINAIS}

Em 1996, o premiado diretor, escritor e produtor grego Nicholas Franghias, naturalizado americano em 2019, com bastante trânsito nos Estados Unidos e no Reino Unido, onde estudou e ajuda a promover diretores gregos ao redor do mundo, lançou o documentário Lysipos Epoisen, Lísipo me fez: Trata-se de retratar, em uma linguagem poética e exibindo várias obras de arte, aspectos da vida de Lísipo, filho de escultor que escolhera o bronze como material de trabalho, mas cujas peças chegaram até nós apenas em cópias de mármore. Vivendo no século quarto (390-300), o filho de Policleto foi o único artista autorizado por Alexandre a retratá-lo. O documentário, falado em grego moderno, com legendas em inglês, começa com considerações sobre luz (phos) e tempo (chronos) como elementos do próprio cinema. Em seguida, os créditos e o texto foram feitos pelo arqueólogo Paolo Moreno, professor de arqueologia da Universidade de Roma III, que também participa como entrevistado e assinando alguns textos. É interessante que é também tratado como "mythical sculptor", embora seus méritos tenham sido de introduzir inovações dramáticas e de estilo na estatuária, iniciando a chamada era Helenística.

Os dois narradores da jornada, Espírito do Bronze e do Mármore, dos quais vemos apenas a sombras, narram a vida de Lísipo em função do fato de ter sido ele o "fazedor de imagens de Alexandre". O documentário - gênero que pretende passar um grau de verdade maior do que o da ficção, trazendo à tela um numismata famoso e respeitado, pode servir de boa metáfora para os filmes que comentei acima sobre Alexandre. De fato, ainda que se busque retratar um personagem histórico, não há como não ficcionalizar. A presença do mármore pode realçar, a meu ver, o que Worthington alertou: a literatura de segunda mão, baseada em histórias que eram de pessoas mais próximas de Alexandre, como o escultor, que o viu e retratou no bronze, mais durável, a não ser que seja fundido para outras finalidades mais práticas e imediatas. Como disse um espectador, "You have to experience it", ${ }^{64}$ ou seja, ele nos (co)move. A meu ver, a função, que é a de ser um retrato a partir de obras, remete

\footnotetext{
${ }^{63} \mathrm{O}$ registro mais antigo na Europa da lenda de Aristóteles sendo cavalgado por uma princesa indiana (Phyllis na tradição alemã), por quem Alexandre se apaixonara, parece vir de Henri d'Andeli, trovador do século XIII, que se inspirou em um conto árabe, "O vizir selado e bridado", embora hoje se atribua a peça a Henri de Valenciennes. Há uma vasta iconografia dessa lenda e também análises instigantes sobre sua transmissão, dentre as quais, a de Ilina (2015).

${ }^{64}$ Ponti (2008).
} 
para a fama do seu mais famoso modelo, e o branco do mármore apaga as marcas mais duras do bronze. ${ }^{65}$

Destarte, para concluir, gostaria de lembrar que Fernando Pessoa, no poema que citei no início deste artigo, Ulisses, afirma que "O mito é o nada que é tudo". Imprima-se na tela a lenda - como fez John Ford, ao (re)criar o mito do herói no western -, pois ela poderá alimentar a história, e por ela também ser alimentada, mas sem que uma anule a outra. Por fim, ainda que essas ligações entre a história e a ficção, entre política e filosofia e, em outra perspectiva, entre Aristóteles e Alexandre, possam ser perigosas, não deixam de ser, também, fontes de pesquisa preciosas. ${ }^{66}$

\section{REFERÊNCIAS}

ALEXANDER. Direção: Oliver Stone. EUA: Warner Bros, 2004. (175 min.), son., color. Inglês com legendas em português, on line, acessível na Netflix.

ALEXANDER. Direção: Oliver Stone. EUA: Warner Bros, 2004. DVD (175 min./207 min. ultimate cut.), son., color. Inglês com legendas em português.

ALEXANDER THE GREAT. Director: Robert Rossen. EUA: CBC Films S.A., 1956. DVD (136 min.). Inglês com legendas em português.

ARISTOTLE; BARNES, John (ed.). The complete works of Aristotle. The revised Oxford translation. Princeton: Princeton University Press, 1984. 2 v.

ARRIAN. The campaigns of Alexander. Transl. A. de Sélincourt. Introd. and notes: J. R. Hamilton. London: Penguin, 1971.

ASIRVATHAM, Sulochana R. Alexander the philosopher in the Greco-Roman, Persian and Arabic traditions. In: STONEMAN, Richard; NETTON, Ian; ERICKSON, Kyle (ed.). The Alexander Romance in Persia and the East. Groningen: Barkhuis, 2012. p. 311-26. (Ancient Narrative Supplementum, 15).

AYRES JR., Antonio T. As visões no Orto do Esposo: construção e interpretação. Dissertação (Mestrado em Literatura Portuguesa) - Faculdade de Filosofia, Letras e Ciências Humanas, Universidade de São Paulo, 2017. Disponível em: https://teses.usp.br/teses/ disponiveis/8/8150/tde-07062017-124549/pt-br.php. Acesso em: 5 fev. 2020.

\footnotetext{
${ }^{65}$ No filme de Oliver Stone, enquanto Alexandre lê uma carta de sua mãe, aparece um escultor trabalhando em uma estátua de mármore, em seu quarto, que se supõe representaria Lísipo.

${ }^{66}$ Agradeço ao professor Pedro Ipiranga Jr. pelo convite para participar do VIII Simpósio Antigos e Modernos: Alexandre... Alexandre!, realizado em 2018, na Universidade Federal do Paraná, em Curitiba, no qual apresentei a palestra Alexandre Trimegisto, que foi o ponto de partida para este texto. Agradeço, também, aos professores Elias Koulakiotis e Ian Worthington, que aceitaram os convites para visitar a Universidade Federal de Minas Gerais, em 2018 e 2019, respectivamente, ocasião em que vários aspectos ligados a este trabalho foram elaborados, e ao Igor Cardoso, pelas observações enriquecedoras.
} 
BERTI, Irene; MORCILLO, Marta G. Does Greece - and the cinema - need another Alexander? In: (ed.). Hellas on screen: cinematic receptions of Ancient History, Literature and Myth. Heidelberg: Franz Steiner Verlag, 2008. p. 9-21. (Habes, 45).

BLANSHARD, Alastair. Alexander as Glorious Failure: The Case of Robert Rossen's Alexander the Great (1956). In: MOORE, Kenneth (ed.). Brill's companion to the reception of Alexander the Great. Leiden: Brill, 2018. p. 675-93.

BOSWORTH, Albert B. Conquest and empire: The reign of Alexander the Great. Cambridge: Cambridge University Press, 1995.

CARTLEDGE, Paul; GREENLAND, Fiona R. (ed.). Responses to Oliver Stone's Alexander. Film, History, and Cultural Studies. Madison: University of Wisconsin Press, 2010.

CHANIOTIS, Angelos. Making Alexander fit for the twenty-first century: Oliver Stone's Alexander. In: BERTI, Irene; MORCILLO, Marta G. (ed.). Hellas on screen: cinematic receptions of Ancient History, Literature and Myth. Heidelberg: Franz Steiner Verlag, 2008. p. 185-201. (Habes, 45).

CHERRY, John. F. Blockbuster! Museum Response to Alexander the Great. In: CARTLEDGE, Paul; GREENLAND, Fiona. R. (ed.). Responses to Oliver Stone's Alexander: Film, History, and Cultural Studies. Madison: University of Wisconsin Press, 2010. p. 305-35.

COELHO, Maria Cecilia M. N. Agamêmnon nas terras da rainha: as versões de Browning, Rattigan, Asquith e Figgis. Aletria, v. 19, n. especial, p. 163-76, jul.-dez. 2009. DOI: http://dx.doi.org/10.17851/2317-2096.19.4.163-176

COELHO, Maria Cecilia M. N. Dispositivi dimostrativi utilizzati in tre modelli di difesa: Ippolito, Palamede e Socrate. In: DE LUISE, Fulvia; STAVRU, Alexander (ed.). Socratica III Studies on Socrates, the Socratics, and the Ancient Socratic Literature. Sankt Augustin: Academia, 2013. p. 13-24.

COELHO, Maria Cecilia M. N. Helena de Tróia no cinema nacional?! - O Senhor se admira!?? - Não, não, absolutamente.... Letras Clássicas, ano 12, n. 12, p. 251-8, 2008. DOI: https://doi. org/10.11606/issn.2358-3150.v0i12p251-258

COELHO, Maria Cecilia M. N. Horses for ladies, high-riding women and whores. In: MATHESON, Sue (ed.). A fistful of icons: essays on frontier fixtures of the American Western. Jefferson: McFarland, 2017. p. 78-88.

COLEMAN, Kathleen M. The Pedant Goes to Hollywood: The Role of Academic Consultant. In: WINKLER, Martin M. (ed.). Gladiator: film and History. Malden, MA: Blackwell, 2004. p. 45-52.

ESTEVES, Elisa. Figuras heroicas no Horto do Esposo. Diacrítica - Revista do Centro de Estudos Humanísticos, v. 28, p. 171-80, 2014. 
FERNÁNDEZ, Jordi M. Alejandro Magno según Robert Rossen. In: VENTURA, Fernando J. (ed.). Cine e Historia(s): maneras de relatar el pasado con imágenes. Paris: Université Paris Sud, 2015b. p. 407-22.

FERNÁNDEZ, Jordi M. Sikandar, Indian poetics and Ocidental power. In: MARCHENA, Olavo L.; MURILLO, Maria D. P. (ed.). El poder a través de la representación fílmica. Paris: Université Paris Sud, 2015a. p. 197-210.

FERNÁNDEZ, Jordi M. The golden age of Hindustani cinema: Sohrab Modi and Urdu cinema. Metakinema, n. 16, n.p., 2015c. Disponível em: http://www.metakinema.es/ metakineman16s4a1_Sohrab_Modi_Urdu_Hindustani_Jordi_Macarro_Fernandez.html. Acesso em: 5 fev. 2020.

FOX, Robin L. Alexander on stage, a critical appraisal of Rattigan's Adventure Story. In: CARTLEDGE, Paul; GREENLAND, Fiona R. (ed.). Responses to Oliver Stone's Alexander: Film, History, and Cultural Studies. Madison: University of Wisconsin Press, 2010. p. 55-91.

GAMEL, Mary-Kay. Revising 'authenticity' in staging ancient Mediterranean drama. In: HALL, Edith; HARROP, Stephe (ed.). Theorising performance. London: Bristol Classical Press, 2010. p. 153-69.

HEATH, Malcom. Aristotle on natural slavery. Phronesis, v. 53, p. 453-70, 2008.

IDAHO, Doc. Alexander. Comparison: theatrical version; unrated final cut. In: WURM, Gerald (dir.). Movie-Censorship.com. Publicação em meio eletrônico que oferece comparações entre as diferentes versões de um filme. Jan. 2011. Disponível em: https://www.moviecensorship.com/report.php?ID=3788. Acesso em: 19 mar. 2020.

ILINA, Alexandra. Se moquer d'Aristote au Moyen Âge. In: EGEDI-KOVÁCS, Emese (ed.). Byzance et l'Occident II: Tradition, transmission, traduction. Budapest: Collège Eötvös József ELTE, 2015. p. 63-73.

KOULAKIOTIS, Ilias. Attic Orators on Alexander the Great. In: MOORE, K. (ed.). Brill's companion to the reception of Alexander the Great. Leiden: Brill, 2018a. p. 41-71.

KOULAKIOTIS, Ilias. Intellectuals and leaders in the late Classical period: aspects of the academy's relationship to the Macedonian kings. In: JORNADAS DE RETÓRICA E ARGUMENTAÇÃO, Belo Horizonte, UFMG, nov. 2018b. p. 1-20.

LYSIPPOS Epoesen. Direção: Nicholas Franghias. Greece: Giannikos/NF Emberfilms, 1996. AVD (56 min), son., color, 16 mm/Beta SP, grego moderno com legendas em inglês. Disponível em: https:/ / filmfreeway.com/809100. Acesso em: 5 fev. 2020.

LOPES DA COSTA, Lorena. Cavalos que choram: cantos XVI e XVII da Ilíada e(m) registros de João Guimarães Rosa. Nuntius Antiquus, v. 15, n. 2, p. 103-22, 2019. DOI: http:/ /dx.doi. org/10.17851/1983-3636.15.2.103-122

MALER, Bertil (ed.). Orto do Esposo. Rio de Janeiro: MEC/INL, 1956. 2 v. 
MALHOTRA, A. P. S. Sikandar (1941). The Hindu, Chennai, 29 abr. 2011. Seção Friday Review. Disponível para assinantes em: https://www.thehindu.com/todays-paper/tp-features/tpfridayreview/Sikandar-1941/article14741524.ece. Disponível para usuários do Facebook na página Imprints and Images of Indian Film Music. Acesso em: 29 maio 2019.

MEYERS, Tobias. 'What if We Had a War and Wverybody Came?: War as Spectacle and the Duel of Iliad 3. In: BAKOGIANNI, Anastasia.; HOPE, Valerie (ed.). War as Spectacle: Ancient and Modern Perspectives on the Display of Armed Conflict. London: Bloomsbury Academic, 2015. p. 25-42.

MOSSÉ, Claude. Alexandre o Grande. Tradução Anamaria Skinner. São Paulo: Estação Liberdade, 2004.

MOSSÉ, Claude. O processo de Sócrates. Rio de Janeiro: Zahar, 1987.

MORRIS, Alexandra F. The conscience of the king: Alexander the Great and the Ancient disable. In: MOORE, Kenneth (ed.). Brill's companion to the reception of Alexander the Great. Leiden: Brill, 2018. p. 823-44.

MORENO, Paolo. Immagini di Alessandro: monete e storia, in Il significato delle immagini, Numismatica, Arte, Filologia, Storia. In: PERA, Rosella (ed.). Atti del Secondo Incontro internazionale di studio del Lexicon Iconographicum Numismaticae. Roma: Giorgio Bretschneider Editore, 2012. p. 153-70, tav. 30-5.

PAPILLON, Terence. Isocrates. In: WORTHINGTON, Ian (ed.). A companion to Greek Rhetoric. Malden, MA: Blackwell, 2007. p. 58-74.

PAUL, Joanna. Oliver Stone's Alexander and the cinematic Epic tradition. In: CARTLEDGE, Paul; GREENLAND, Fiona. R. (ed.). Responses to Oliver Stone's Alexander: Film, History, and Cultural Studies. Madison: University of Wisconsin Press, 2010. p. 15-35.

PELLING, Christopher. Is death the end? Closure in Plutarch's Lives. In: . Plutarch and History. Duckworth: The Classical Press of Wales and Duckworth, 2002b. p. 365-86.

PETROVIC, Ivana. Plutarch's and Stone's Alexander. In: BERTI, Irene; MORCILLO, Marta G. (ed.). Hellas on screen: cinematic receptions of Ancient History, Literature and Myth Heidelberg: Franz Steiner Verlag, 2008. p. 163-82. (Habes, 45).

PINHEIRO, Joaquim. A contextualização temática da morte nas biografias de Plutarco: alguns exemplos. Classica, v. 31, n. 2, p. 101-12, 2018.

DOI: https://doi.org/10.24277/classica.v31i2.694

PLATT, Verity. Viewing the past: cinematic exegesis caverns of Macedonia. In: CARTLEDGE, Paul; GREENLAND, Fiona R. (ed.). Responses to Oliver Stone's Alexander: Film, History, and Cultural Studies. Madison: University of Wisconsin Press, 2010. p. 285-303.

PLUTARCH. Moralia. English translation by Frank Cole Babbitt. Cambridge: Harvard University Press; London: William Heinemann, 1936. 
PLUTARCH. Plutarch's Lives. English translation by Bernadotte Perrin. Cambridge: Harvard University Press; London: William Heinemann, 1919. v. 7.

PLUTARQUE. Vies. Traduction de Robert Flacelière et Émile Chambry. Paris: Les Belles Lettres, 1975. t. 9.

PONTI, Silvio. Lysippos Epoesen (1996): Unique - I've never seen anything like it before. In: IMDB, 28 abr. 2008. Seção Reviews. Disponível em: https://www.imdb.com/user/ ur19187650/?ref_=tt_urv. Acesso em: 19 mar. 2020.

POTHUKUSHI, Madhavi. Prithviraj Kapoor's Sikandar was banned in British cantonments because it was nationalist. The Print, New Delhi, 2 June 2019. Seção Opinion. Disponível em: https:// theprint.in/opinion/prithviraj-kapoors-sikandar-banned-in-british-cantonmentsbecause-it-was-nationalistic/244087/ Acesso em: 12 dez. 2019.

RABELO, Laura Cohen. Vida e feitos de Alexandre da Macedônia: tradução e comentário de um Romance de Alexandre grego. Dissertação (Mestrado em Estudos Literários) - Programa de Pós-graduação em Estudos Literários da Faculdade de Letras, Universidade Federal de Minas Gerais, Belo Horizonte, 2017.

SHAHABUDIN, Kim. The Appearance of History: Robert Rossen's Alexander the Great. In: CARTLEDGE, Paul; GREENLAND, Fiona R. (ed.). Responses to Oliver Stone's Alexander: Film, History, and Cultural Studies. Madison: University of Wisconsin Press, 2010. p. 92-116.

ROSSETTI, Livio. Introdução à filosofia antiga: premissas filológicas e outras ferramentas de trabalho. Tradução de Elcio V. Filho. São Paulo: Paulus, 2006.

SMITH, Nicholas D. Aristotle's theory of natural slavery. Phoenix, v. 37, n. 2, p. 109-22, 1983.

SIKANDAR. Direção: Sohab Modi. India: Minerva Movietone, 1941, (141 min.), son., p\&b, 35 mm, urdu com legendas em inglês. Disponível em: https://www.youtube.com/ watch? $\mathrm{v}=\mathrm{Cr} 8 \mathrm{~S} 5 \mathrm{~Wb} 3 \mathrm{O}-\mathrm{s}$. Acesso em: 19 mar. 2019.

SOLOMON, John. The Ancient world in the cinema. New Haven: Yale University Press, 2001.

SOLOMON, John. The popular reception of Alexander. In: CARTLEDGE, Paul; GREENLAND, Fiona R. (ed.). Responses to Oliver Stone's Alexander: Film, History, and Cultural Studies. Madison: University of Wisconsin Press, 2010. p. 36-51.

STONE, Oliver. Afterword. In: CARTLEDGE, Paul; GREENLAND, Fiona R. (ed.). Responses to Oliver Stone's Alexander. Film, History, and Cultural Studies. Madison: University of Wisconsin Press, 2010. p. 337-41.

TARN, William. Alexander the Great. Cambridge: Cambridge University Press, 1948. 2 v.

WIEBER, Anja. Celluloid Alexander(s): a hero from the past as role model for the present? In: BERTI, Irene; MORCILLO, Marta G. (ed.). Hellas on screen: cinematic receptions of Ancient History, Literature and Myth. Heidelberg: Franz Steiner Verlag, 2008. p. 147-62. (Habes, 45). 
WINKLER, Martin M. Cinema and Classical texts: Apollo's new light. Cambridge: Cambridge University Press, 2009.

WINKLER, Martin M. (ed.). Gladiator: film and History. Malden, MA: Blackwell, 2004.

WINKLER, Martin M. (ed.). Troy: from Homer's Iliad to Hollywood Epic. Malden, MA: Blackwell, 2007.

WORTHINGTON, Ian. Alexander the Great. A reader. London: Routledge, 2003.

WORTHINGTON, Ian. Alexander the Great and Philip II. In: JORNADAS DE RETÓRICA E ARGUMENTAÇÃO, Belo Horizonte, UFMG, nov. 2019.

WORTHINGTON, Ian. By the spear: Philip II, Alexander the Great, and the rise and fall of the Macedonian Empire. New York: Oxford University Press, 2014. 